\title{
Faaliyet Raporlarında Metin Siralamasının Profesyonel Olmayan Yatırımcı Kararlarına Etkisi Üzerine Bir Araştırma
}

\author{
A Research on the Effects of Textual Presentation Order in Annual Reports on Non- \\ Professional Investors' Decisions
}

\author{
Yusuf AVŞAR* \\ Ozan ÖZDEMIR* ${ }^{* *}$
}

\begin{abstract}
$\ddot{O} Z$
Profesyonel olmayan yattrimclların karar alma sürecinde, faaliyet raporlarindaki metin stralamast ile grafiklerin bulunmasının bir etkisinin olup olmadığını tespit etmeyi amaçlayan araştırmada anket yöntemi uygulanmış olup, 422 ögrrenciden örneklem üzerinde çalışma yürütülmüstür. Araştırmanın evrenini Süleyman Demirel Üniversitesi İ̈BF ögrencileri oluşturmaktadır. Anket kapsamina SDÜ'de eğitim görüp üçüncü ve dördüncü sinıfa devam eden Issletme, Bankacllik ve Finans, İktisat ve Maliye bölümleri bașta olmak üzere diğer bölüm ve lisansüstü ögrrencileri de dâhil edilmiştir. Çalışmada, Borsa İstanbul'da işlem gören bir market zinciri şirketine ait 2018 yıll faaliyet raporunu kullanılmıştır. Sonuçların istatistiki anlamlılı̆ı̆n test etmek için Mann- Whitney U Test kullanılmuştır.

Araştırmada bilgi aktarımında planlı sunum sıralanmasından dolayl, profesyonel olmayan yatırımcların yenilik etkisine duyarl olduklart sonucuna varllmıştır. Başka bir ifade ile yatırtmcının, faaliyet raporlarında olumlu bilgilerin ve gelişmelerin raporun sonunda olduğunda, şirkete bakış açısı olumlu olmaktadır, bu sonuç olumsuz bilgiler için de geçerlidir. Olumsuz bilgilerden hemen sonra olumlu bir grafiğin sunulması, yatırımcının kararı üzerinde neredeyse hiçbir etkiye sahip olmadı̆̆ sonucuna varılmıştır. Genel olarak, yenilik etkisi, İ̈BF öğrencileri ve özellikle Maliye bölümünde ortaya çıkmıştır ve IIIBF ögrencisi olmayan kontrol grubunda bu etki bulunmamıştır. Tüm öğrencilerin sonuçları; bilgi sunum sıralanmasının yatırım kararını etkilemezken, yatırım miktarı ile gelir beklentisi üzerinde bir etkisi bulunmustur. Bütün olarak (Bankaclllk ve Finans, İșletme, İktisat ve Maliye) bölümlerin sonuçları, bilgi sunum sıralanmasının yatırım kararı, yatırım miktarl, gelir beklentisi ile şirketin değerlendirilmesini etkilemiş̧tir. İ̈BF diğer bölümlerde okuyan ögrencilerin durumunda, yatırım kararına ilişkin öncelik etkisi bulunmuştur. Bulunan yenilik etkisi, erkek ve finansal okuryazarlık düzeyi yüksek olan ögrencilerin kararlarında bulunmayıp sadece kadın ve finansal okuryazarlı düzeyi düşük olan ögrenciler kararlarında bulunmuştur.
\end{abstract}

Faaliyet raporların hazırlama sürecinde; bu raporun içerdiği bilgilerin doğru olmast ile istatistiki verilerin ve analizlerin sade ve açık olması dikkat edilmesi gereken hususların başındadır. Ancak, araştırmada ulaşılan bulgular, bilgilerde bir değisşiklik olmadı̆̆g halde, bilgi sunum sıralanmasında yapılan değisşikliklerin profesyonel olmayan yatırımcının kararını, şirketin lehine etkileyebileceğini göstermektedir. Ayrıca, sonuçlar bu tür belgelerin üzerindeki uygulanan denetim işlemlerinin güçlendirilmesinin gerekliliğini göstermektedir.

ANAHTAR KELIMELER

Faaliyet raporları, Yenilik etkisi, Öncelik etkisi, Yatırım Analizi, Mann- Whitney U.

\begin{abstract}
This paper's aim is to reveal the influence of both the text order and the graphics use in the annual reports on nonprofessional investors' decision.

A total of 422 Participants were recruited for the experiment from undergraduate classes and Master students in Business Management, Economy, Public Finance and Banking \& Finance along with other departments students of Faculty of Economics and Administrative Sciences and non-economic faculties students at Suleyman Demirel University. Annual report, published in 2018, used in the paper belongs to a supermarket chain listed in Borsa Istanbul. In order to keep participants' answers objective as possible, the company's name has been changed with a fictional one. Since obtained data were not normally distributed, Mann- Whitney U Test was used to assure the results' statistic meaningfulness.
\end{abstract}

\footnotetext{
* Süleyman Demirel Üniversitesi, İktisadi ve İdari Bilimler Fakültesi, Bankacılık ve Finans Bölümü, Isparta/Türkiye. ausharyoussef@ gmail.com, ORCID: 0000-0001-7372-5799

** Dr. Öğr. Üyesi, Süleyman Demirel Üniversitesi, İktisadi ve İdari Bilimler Fakültesi, Bankacılık ve Finans Bölümü, Isparta/Türkiye. ozanozdemir@sdu.edu.tr. ORCID: 0000-0002-7579-9422
} 
Overall results imply that there is a recency effect occurred by non-professional investors due to the planned presentation ordering of narrative information. In other words, when the investor sees positive information and developments at the end of the annual report, their viewpoint toward the company will be positive. This result also applies to the negative information. In addition, including a positive graph right after the bad news had almost no effect on the non-professional investors' decision. In general, specifically the Public Finance Department, the recency effect took place in Economic and Administrative Sciences Faculty students' case and was not witnessed in the case of non-economic and administrative students. For all students, while the textual order had no effect on the investing decision, it has an effect on both investment amount and gain expectancy. For the case of Banking \& Finance, Public Finance, Business and Economic students, which represents the main data source in our study, textual order had an effect on investing decision, investment amount, gain expectancy and the general view toward the company. A primacy effect was found in the case of other Economic and Administrative departments students vis-à-vis the investing decision. While Recency effect was found in female students and students who have weak financial literacy, it was not found in the case of male students and students who have strong financial literacy.

Although the information included in the annual reports has to be correct and objective, keeping this information nonmanipulated while changing the information presentation order has significant effects on the non-professional investor decision in favor of the company. Furthermore, the results suggest to strengthen the audit procedures applied to such documents.

\section{KEYWORDS}

Annual reports, Recency effect, Primacy effect, Investment Analysis, Mann- Whitney $U$

\begin{tabular}{|c|c|c|}
\hline \multicolumn{2}{|r|}{$\begin{array}{c}\text { Makale Geliş Tarihi / Submission Date } \\
\text { 09.08.2019 }\end{array}$} & $\begin{array}{l}\text { Makale Kabul Tarihi / Date of Acceptance } \\
20.04 .2020\end{array}$ \\
\hline Atıf & $\begin{array}{l}\text { Avşar, Y. ve Özdemir, O. (2020). I } \\
\text { Kararlarına Etkisi Üzerine Bir Araştır } \\
\text { 257-286. }\end{array}$ & $\begin{array}{l}\text { Metin Sıralamasının Profesyonel Olmayan Yatırımc1 } \\
\text { i Sosyal Bilimler Meslek Yüksekokulu Dergisi, } 23 \text { (1), }\end{array}$ \\
\hline
\end{tabular}




\section{GİRIŞ}

Ekonomik olayların ve faaliyetlerin nicelleştirilmesine önem verilerek, muhasebe genel olarak sayı odaklı bir disiplin/düzen olarak görülmesine rağmen, şirketler tarafından yayınlanan haberler (hisse senedi fiyatı, satışlar, kâr gibi bilgiler) çoğu zaman ilave açıklamaları kapsayacak şekilde ayrı olarak sunulmamaktadır. Bu nedenle, şirketin faaliyetleri anlatılarak, dil, haberlerin belgedeki yerleri ve sıralanmaları gibi değişkenlerin ile muhasebe bağlantısı, kurumsal muhasebe sonuçlarını iletme konusundaki rolü giderek artan bir ilgi görmektedir (Riley ve Yen, 2019).

Y1llık faaliyet raporu, yönetim organı tarafından Türk Ticaret Kanunu ve "Şirketlerin Yıllık Faaliyet Raporunun Asgari İçeriğinin Belirlenmesi Hakkında Yönetmelik" hükümlerine göre düzenlenen, şirketin ilgili yıla ilişkin faaliyetlerinin akışı ile her yönüyle finansal durumunun doğru, eksiksiz, dolambaçsız, gerçeğe uygun ve dürüst bir şekilde yansıtıldığ 1 , şirketin gelişmesinin ve karşılaşılması muhtemel risklerin belirtildiği dokümandır (Deloitte, 2014: 5). Yıllık faaliyet raporları, çalışanlar, sendikalar, satıcılar ve düzenleyiciler dâhil, bir şirketin yönetimi tarafından hissedarlara ve paydaşlara hazırlanan ve yıl boyunca faaliyetlerde ne olduğunu açıklayan bir belgedir. Faaliyet raporlarının içeriği ve sunum ile ilgili genel standartlar yoktur ve bazı şirketler yerel otoriteler tarafindan bir zorunluluk olmadıkça bu tür bir raporu hazırlamaz. Ancak, bu belge, başka bir yerden kolayca keşfedilemeyecek önemli bilgileri içermekte olup hazırlık/hazırlama süreci önemli derecede zaman ve çaba harcanmasını gerektirmektedir (Kennon, 2018). Faaliyet raporu, Ticaret Şirketlerinin Gümrük ve Ticaret Bakanlığınca Denetlenmesi Hakkında Yönetmeliğin "Denetime Konu İşlemler” başlıklı 5/1 - k maddesine göre denetime konu işlemler içerisinde sayılmıştır (Kumkale, 2016). 6102 sayılı Türk Ticaret Kanunu madde 514 fikra 1 uyarınca, yönetim kurulu, geçmiş hesap dönemine ait, Türkiye Muhasebe Standartlarında öngörülmüş bulunan finansal tablolarını, eklerini ve yönetim kurulunun yıllık faaliyet raporunu, bilanço gününü izleyen hesap döneminin ilk üç ayı içinde hazırlar ve genel kurula sunar (TTK, 2011).

Faaliyet raporlarının yapısında genel olarak iki farklı bilgi çeşidinin bulunduğu görülmektedir; ilki ağırlıklı olarak şirketin vermek istediği mesajları vurgulayan, yönetim kurulu başkanının mesajı, şirkete ait vizyon, misyon ve değerleri, şirketin yönetim kadrosunu ve insan kaynaklarını ele alan bilgileri ayrıca şirketin gerçekleştirdiği sosyal sorumluluk faaliyetlerini ve kültürel etkinlikleri içerir. İkinci önemli kapsam ise mali tablolar ve ilgili dipnotların, denetim raporunun, analiz, grafik, hisse senedi performansı, yıllık performans değerlendirmeleri ile finansal verilerin açıklandığı ve verilen mesajların rakamlarla desteklendiği bölümlerdir (Y1ldırım, 2009).

Faaliyet raporlarında önem arz eden konu, mali tablolar ve raporlarda bulunmayan şekil ve grafiklerdir. Faaliyet raporu, başkan mesajı vs. bu tür şirketlerin rakamsal bilgilerin yanında yayınladığı sayısal olamayan bilgilere, yabanc1 literatürde "Accounting Narratives" veya Muhasebe Anlatıları olarak ifade edilir. Faaliyet raporları bu yönüyle, yasal açıklama kısıtlamalarının ve zorunluluklarının dışında, şirketin stratejileri ve hedeflerini destekleyerek, yönetim tarafindan ayarlanabilen veya manipüle edilebilen bir değişkendir (Adelberg , 1979). Yatırımcıların kararlarına etki etme ve kendi menfaatlerine/lehine yönlendirmek amacıyla, şirketlerin yönetimleri tarafından yapılan, grafiklerin ölçümlerini bozmak, bilgilerin sıralanmasını değiştirmek, iyi haberlerin sebeplerini kendi çabasına atfedip kötü bilgileri devlet politikaları ve enflasyon gibi dışsal ve kontrol edilemeyen faktörlerin üstüne atmak, bilginin kötü veya iyi olduğuna göre kullanılan yazılış1 manipüle etmek gibi çeşitli faktörler, farklı ülkelerde araştırma alanı olarak oldukça önem gören bir konudur. Çalışmada, faaliyet raporlarında metin sıralanmasının değiştirilmesi ölçülen temel faktör olduğu için, diğer faktörlerle ilgili yapılan çalışmalardan kısaca bahsedilmiştir.

Beattie ve Jones (1992) yapmış oldukları çalışmada, İngiltere'de 240 büyük şirketinin yıllık faaliyet raporlarının analizinden, grafik kullanımının niteliğini ve kapsamını araştırmışlardır. İyi performansa sahip olan şirketlerin finansal grafikleri kullanma sıklığının daha yüksek olduğunu açıklamışlardır. Bu grafiklerin \% 30'unda sayısal veriyi grafik gösterime dönüştürmede ölçüm bozulmaları tespit edilerek, gerçek sayısal verilerin ortalama \%10,7 oranında abartıldığı da keşfedilmiştir. Ölçüm bozulmasının etkisi genellikle şirketin performansını daha iyi göstermek içindir. Sonuçta, yazarlar, finansal grafiklerin etkili iletişimi geliştirme potansiyellerini yerine getirmediği sonucuna varmışlar ve buna göre, denetçilerin ve yöneticilerin bu alandaki sorumluluklarının daha belirgin hale getirilmesi gerektiğini belirtmişlerdir. Beattie ve Jones (2000), 1988-1992 döneminde, İngiltere'de en büyük 137 şirketin faaliyet raporlarını incelemişlerdir. Şirketlerin faaliyet raporlarındaki finansal grafiklerin, okuyucunun şirket performansı üzerindeki izlenimini olumlu bir şekilde yönetmek için kullanıldığ 1 ve bu nedenle faaliyet raporlamasında bir önyarg1 bulunduğu sonucuna varmışlardır. Clatworthy ve Jones (2003), Birleşik Krallık'ta, borsada listelenen 100 şirket üzerinde başkan mesajı kullanımını araştırarak, performansı iyi olan şirketlerin kötü haberlerden daha fazla iyi haberlere 
odaklandığını, düşük performans gösteren şirketlerin performanslarının düşüklüğünün niteliğini ve sebeplerini açıklamaktan kaçındıklarını sonucuna ulaşmıştır.

Hines'e (1982) göre, hissedarların yıllık raporları kullanıp kullanmama sorusuyla doğrudan ilgilenen iki araştırma alanı bulunmaktadır. İlk olarak, Etkin Piyasalar Hipotezi (EMH), yıllık faaliyet raporların hissedarlara kullanım için çok geç yayınlandığını öne sürmektedir. İkincisi, yatırımcı anketleri, hissedarların yıllık faaliyet raporlarını kullandığını göstermektedir. Sonuçta, yıllık faaliyet raporlarının hissedarlara yararlı olduğu anlaşılmaktadır. Bu raporların yayılmasına karşı, kısa vadeli borsaların tepki göstermemesine rağmen, faaliyet raporların, özellikle yatırımcıların uzun vadeli yatırım karar vermesinde önemli bir girdi olabileceğine işaret etmiştir.

İşletmelerin faaliyet sonuçlarına ulaşılabilecek finansal ve finansal olmayan bilgiler içeren farklı raporlar da sunulmaktadır. Entegre raporlama kapsamında finansal bilgilerin yanı sira finansal olmayan bilgilerin yer aldığı sürdürülebilirlik raporları hazırlanıp sunulmaktadır. Genel anlamda sürdürülebilirlik raporlaması, şirketlerin günlük faaliyetlerinin ekonomik, çevresel ve sosyal etkilerini anlattıkları raporlardır (Borsa İstanbul, 2014: 33). Sürdürülebilirlik raporlaması ile finansal raporlama arasında bilgi ihtiyacını giderme amaçlı olarak ortaya çıkmaları açısından bir benzerliğin söz konusu olup sürdürülebilirlik raporlarının bir bildirim aracı olmasının yanısıra aynı zamanda finansal ve finansal olmayan bilgiler arasındaki ilişkiyi açıklama fonksiyonu da bulunmaktadır. (Saban vd., 2017: 105; Karğin vd., 2013: 27).

Metin sıralanmasının bireylerin psikolojisi üzerindeki etkisi literatürde oldukça önem taşımaktadır. Finans ile muhasebe gibi alanlarda araştırıldığı gibi, bilgisayar, spor, tıp, hukuk ve siyaset gibi diğer alanlarda da sıklıkla araştırılmaktadır; (Greenlees vd., 2007; Miller ve Krosnick, 1998; Shaw vd., 2012).

İnancın güncellenmesi (Belief updating), insan yarg1 ve karar vermesinin çok önemli bir yönüdür. Bir kanaatten diğerine yeni kanıtlar 1 şı̆̆ında geçmek, insanoğlunun değişen bilgi koşullarına uyum sağlama yeteneğini yansıtır. Dolayısıyla inanç/tutum güncellemesi, zekânın zeminini oluşturan bir faaliyet olarak nitelendirilebilmektedir (Yankova, 2014: 53).

Yapılan inceleme ve deneyimlerde en önemli ampirik sonuçlar, yarg1 ve seçimin yapma sürecindeki bulunan sorularda (görev) görünüşte küçük olan değiş̧ikliklere duyarlılığını göstermiştir. (Payne vd., 1993: 1).

\section{LITERATÜR TARAMASI}

Rey vd. (2019) yaptıkları çalışmalarında, dört arabayı değerlendirmek üzere, aynı katılımcıya artarda farklı dört anket verilmiş. Dört anketin içerdiği araba özellikleri aynı arabaya ait olmasına rağmen, katılımcılar, özelliklerin sıralanmasının değişiminden dolayı arabayı çeşitli şekillerde değerlendirmişlerdir.

Sıralanma etkilerine, pratikte herhangi bir şey neden olabilir ve bu yüzden kontrol edilmesi oldukça zordur. Glen (2016), sıralanma etkilerine neden olabilecek birkaç olası sebepten bahsetmiştir;

1. Yorulma: Metni okuyanlarının bir veya iki görevden sonra yorulması,

2. Tanıdıklık: Metni okuyanlar, testin veya deneyimimin kapsadığı alana daha tanıdık olduklarında, daha iyi performans gösterebilirler ve

3. Diğer Test Koşulları: Test ortamındaki ısıtma, aydınlatma veya ergonomi gibi faktörler nedeniyle, katılımcıların performansı kademeli olarak iyileşebilir (veya düşebilir).

Katılımcılar sıkılmış ya da yoruldukları için bir deney ya da anket sonunda farklı performans gösterebilirler. $\mathrm{Bu}$ yorulma etkileri, prosedür uzun olduğunda ve tekrarlanmış sorular veya ilgisiz olduğunda daha olasıdır (Psychology, 2019). Buna örnek olarak şu çalışma verilebilir; Baird ve Zelin (2000), yapmış oldukları çalışmada, şirketlerin yıllık faaliyet raporlarındaki sunulan başkan mesajında metin sıralanmasının yatırımcıların üzerindeki etkisini test etmişlerdir. Bir firmanın başkan mesajı, olumlu-olumsuz ile olumsuzolumlu sıralanma şeklinde 2 biçim anketler, 92 yarı zamanlı MBA öğrencilerine rastgele dağıtılmıştır. Çalışmanın sonunda, başkan mesajının başlangıcının, son kısmına göre yatırımcıları daha fazla etkilediği sonucuna varmışlardır.

Miller ve Krosnick (1998) ABD'de Ohio eyaletinin Cuyahoga, Hamilton ve Franklin ilçelerinde 1992 yılında yapılan seçimlerin üzerinde analiz yapmışlardır. Çalışmanın amacı, seçimde adayların isimlerin sıralanmasının, vatandaşın kararının üzerinde bir etkisi olup olmadığını test etmektir. Seçim yarışlarının \%48'inde isim sıralanması vatandaşın kararını etkilemiştir ve hemen hemen çoğu durumda, ilk listelenen adaylar bir avantaja sahip olmuştur. Ayrıca, isim sıralanma etkisi, siyasette bilgisi az olan kişilerin olduğu ilçelerde diğer ilçelere nazaran daha büyük olduğu sonucuna ulaşmışlardır.

Süreç izleme araştırmaları, karar vericilere sunulan alternatiflerin (tercihlerin) özellikleri değiştiğinde, bilgi edinmelerini ve algılama düzeylerini esnek bir şekilde değiştirdiklerini göstermiştir (Senter ve Wedell, 1999: 428). Sıralanma etkileri, üç boyuttaki görevlerin taksonomisine dayanır: görev karmaşıklı̆̆ı, seri uzunluğu ve yanıt biçimi (Tuttle vd., 1997: 92). Bu üç boyut aşağıdaki tabloda ayrıntılı bir şekilde anlatılmıştır; 
Tablo 1. Bilgi Sıralanma Etkileri

\begin{tabular}{|l|l|l|}
\hline Görev/ Soru & Tip & Nitelikler \\
\hline Karmaşıklık & Karmaşık & Çok bilgi \\
& Basit bilgi \\
\hline Seri uzunluğu & Uzun & 20 unsurdan fazla \\
& Kısa & 2 ile 20 unsur \\
\hline Yanıt şekli & Adım adım (Sbs) & $\begin{array}{l}\text { Sunulan her bilgiden sonra sorular } \\
\text { sunulmaktadır. } \\
\end{array}$ \\
& Bülümün sonunda (Eos) & $\begin{array}{l}\text { Tüm bilgilerin sunulmasına } \\
\text { müteakip sorular sunulmaktadır. }\end{array}$ \\
\hline
\end{tabular}

Tablo 1'de görüleceği üzere; metin sıralama ile ilgili çalışmalarda; 1) katılımcıların karşılaştığı bilgileri tanıyıp tanımadıklarına göre basit veya karmaşık sayılmakta, 2) işin (görev) 20 unsurdan fazla sahip olduğunda uzun 20'den az olduğunda ise kısa sayılmaktadır (Yankova, 2014: 61).

Şimdiye kadar yapılan araştırmalarda aynı işlemin farklı koşullar altında araştırılması temeline dayanmaktadır. Deneylerde/deneyimlerde, bir koşul altında deney gören katılımcılar, diğer bir koşul altındaki deneye katılmamaktadırlar. Bu deneylerin en basit biçimi, iki grubun her biri tarafından farklı bir sıra ile alınan A ve B olmak üzere iki metin bilgisi ve diğer bilgi türleri (fotoğraf, şekil, ses vs) vardır. Bir grupta A-B sırası formatında sunulan bilgi diğer gruba B-A formatında sunulmaktadır ve ardından gruplar arasındaki sonuçların farklılığ1 ölçümlenmektedir (Leppink, 2019: 16). Bir hastalık tedavi sürecinde sunulan üç tedavi kombinasyonu veya siralaması altı şekil alabilir $(123,132,231,213,312$ veya 321) ve kombinasyonun değişmesine göre tedaviler de farklı derecelerde etkinin ortaya çıkması beklenir (Glen, 2016).

Pinsker (2011), yapmış olduğu çalışmasında, hem lisans öğrenciler hem de öğrenci olmayan katılımcılar üzerinde metin sıralanma etkisini araştırmıştır. Lisans öğrencilerinin yatırımcı olarak kullanılmasının güvenilir ve doğru olduğuna işaret etmiştir. Yazar, tüm katılımcıların faaliyet raporunun son bölümündeki yer alan bilgilerden etkilendiğini belirtmiştir (Yenilik Etkisi). Elliott vd. (2007) ve Tuttle vd. (1997) çalışmalarında, işletme bölümü mezunu öğrencilerin, profesyonel olmayan yatırımcı olarak araştırmalara dâhil edilmesinin doğru bir yöntem olduğu sonucuna ulaşmışlardır. (Hellmann vd., 2017: 162), işletme ve iktisat bölümlerinden henüz mezun olmayan öğrencilerinin işletme alanlarında tecrübe veya bilgiye sahip olabileceklerini kanıtlamışlardır. Aynı çalışmada yazarlar, işletme ve iktisat lisans öğrencilerinin bir şirketin değerlendirilme sürecindeki, metin sıralanması ve grafiklerin bulunmasının kararları üzerindeki etkisini araştırmışlardır. Olumlu bilgilerin ardından olumsuz bilgileri gören katılımcı, sıralamanın tersini gören katılımcıya göre daha fazla olumsuz bir şekilde şirketi değerlendirdiği sonucuna varmışlardır (Yenilik Etkisi/ Recency effect). Ayrıca, faaliyet raporunda olumlu bilgi içeren bir grafiğin bulunması, şirket hakkında olumsuz görüşe sahip olan yatırımcının kararı üzerinde bir etkisinin olmadığı sonucuna varmışlardır.

LaSalle (1997) etik açıdan sorgulanabilir eylemlerin kabul edilebilirliği konusundaki üniversite öğrencilerinin oluşturduğu yargıların, sunum sıralanmasından etkilenip etkilenmediğini test etmek amaciyla iki deneyim gerçekleştirmiştir. Her iki deneyimde gerçek etik çatışmalar içeren muhasebe meseleleri bulunmuştur. İki deneyimin sonuçları, muhasebe bölümünde okuyan öğrencilerin kararlarında yenilik etkisinin (recency effect) olduğunu desteklemektedir, başka bir ifadeyle, etik tartışmaların kapsadığı bilgilerin sıralanması, öğrencilerin kararlarını etkilemiştir ve bu karar alma sürecin üzerindeki en büyük paya, en son tartışılan meseleler neden olmuştur. Ancak, muhasebe dışı ana dallar için bir öncelik (primacy effect) ya da yenilik etkisi bulunmamıştır. Öncelik etkisi, bir liste verildiğinde sunulan ilk birkaç bilgi hatırlama meylidir (Paul ve Weiss, 2018).

Başka bir çalışmada, bilgi sunumunun sıralanmasın/düzenin, vergi uzmanlarının belirsizlik içeren vergi muameleleri konusundaki düşünceleri üzerindeki etkileri incelenmiştir. Deneyime, bir büyük muhasebe firmasından, müdür/yönetici seviyesinde olan 40 vergi uzmanı katılmıştır. Özellikle, vergi uzmanlarının düşüncelerinin vergi muamelesinin makul veya mantıklı olup olmadığına karar vermeleri istenmiştir. Sonuçlar, vergi uzmanlarının düşünce revizyonlarının bilgi sunum sıralanması/düzeni manipülasyonlarından ya da değişmesinden etkilendiğini göstermektedir (Pei vd., 1990).

Tuttle vd. (1997) tarafından, bilgilendirmelerin/açıklamaların sıralanmasının, piyasa fiyatlarını etkileyip etkilemediğini incelemek için deney yapılmıştır. Deneyde dört bağımsız ticaret turu oluşturularak, altı yatırımcının hisse senetleri için hem satış hem de alış yapabilme olanağı sunulmuştur. Kuramsal varlık piyasalarında bir yenilik etkisine ilişkin önemli kanıtlar bulmuşlardır. Yazarların ulaştıkları sonuçlara göre, şirketler tarafından yapılan açıklamaların son kısmında yer verilen bilgilerin, piyasa açılış fiyatlarının üzerindeki etkisi olduğu sonucuna ulaşılmıştır. Yenilik etkisi, bireylerin listenin ortasındaki sunulan maddelere göre, listenin sonundaki sunulan maddeler için gelişmiş hatırlama kabiliyeti gösterme eğilimidir (Troyer, 
2017). Şekil 1'de gösterildiği gibi, Yenilik etkisi, özellikle listenin uzunluğu arttığında, genellikle Öncelik etkisinden daha güçlüdür.

Şekil 1. Yenilik ve Öncelik Etkisi.



Kaynak: (Recency Effect, 2019).

\section{ARAŞTIRMA}

\subsection{Veri Seti}

Araştırmanın evrenini SDÜ İ̈BF öğrencileri oluşturmaktadır. Anket çalışmasında Süleyman Demirel Üniversitesi’nde eğitim görüp üçüncü ve dördüncü sınıfa devam eden İşletme, Bankacılık ve Finans, İktisat ve Maliye bölümleri başta olmak üzere diğer lisans programlarındaki öğrenciler ve bu öğrencilerin yanında lisansüstü öğrencilerine ulaşılmıştır. Kontrol ve karşılaştırma amacıyla ankete sınırlı sayıda diğer bölümlerden de katılan öğrenciler yer almaktadır. Anket gruplarının cinsiyet ile bilim dallarına göre dağılımı Tablo 2'de yer almaktadır. Hellmann vd. (2017) çalışmasındaki kullanılan testlerden faydalanmıştır. 446 öğrenciye anketler dağıtılmıştır. Anketlerin 24'ü kontrol sorularından alınan cevaplar neticesinde elenmiştir. Çalışma, toplam 422 anketten elde edilen verilerin üzerinde yürütülmüştür.

Tablo 2. Anket Gruplarının Bilim Dallarına Göre Dağılımı

\begin{tabular}{|c|c|c|c|c|c|}
\hline \multirow{2}{*}{ Eğitim dalı } & \multicolumn{3}{|c|}{ Anket grubu } & \multirow{2}{*}{$\begin{array}{c}\text { Toplam } \\
\text { Bölümm } \\
\text { Katılımcı } \\
\text { Sayısı }\end{array}$} & \multirow{2}{*}{ Oran } \\
\hline & +- & +-Grafik & -+ & & \\
\hline Maliye & 22 & 23 & 27 & 72 & $17.1 \%$ \\
\hline İktisat & 17 & 16 & 25 & 58 & $13.7 \%$ \\
\hline Bankacılık ve Finans & 25 & 21 & 51 & 97 & $23.0 \%$ \\
\hline İşletme & 18 & 26 & 26 & 70 & $16.6 \%$ \\
\hline İİB (B) ${ }^{1}$ & 21 & 22 & 19 & 62 & $14.7 \%$ \\
\hline Diğer & 19 & 19 & 24 & 62 & $14.7 \%$ \\
\hline Belirtilmemiş & 0 & 1 & 0 & 1 & $0.2 \%$ \\
\hline Toplam & 122 & 128 & 172 & 422 & $100 \%$ \\
\hline
\end{tabular}

Anket, i) demografik kısmı ile ii) şirket performansını değerlendirme soruları olmak üzere iki bölümden oluşmaktadır. Demografik sorulardan sonra, katılımcılara farazi ${ }^{2}$ bir market zinciri şirketinin 2018 yılı faaliyet raporunun özeti sunulmuştur, ardından şirketin performansını değerlendirmek amacıyla sorular da

\footnotetext{
${ }^{1}$ (Uluslararası İlişkiler, Ekonometri, Siyaset Bil. ve Kamu Yönetimi, Çalışma Ekonomisi ve Endüstri İlişkileri, Sağlık Yönetimi, Turizm İşletmeciliği ve Sosyal Hizmet)

${ }^{2}$ Çalışmada hazırlanan faaliyet raporu, Borsa İstanbul'da işlem gören bir şirketin 2018 yılı faaliyet raporundan yararlanmıştır. Katılımcıların görüşlerini objektif olmasını sağlamak amacıyla şirketin ismi değiştirilmiştir.
} 
sunulmuştur. Yabancı literatürde, bir konu hakkındaki yanıtlanması istenilen bu sorulara task veya görev ismi verilmektedir. Yankova (2014) ve Hogarth ve Einhorn (1992)'un belirttikleri hususlara göre, araştırmamızda sunulan görevler basit ve kısa biçimi almaktadır. Bu biçimin seçilmesi, katılımcıların yorulma ihtimalini elemek ve İktisadi ve İdari Bilimler Fakültesi dışından katılımcıların da bulunmasıdır.

Anketler; i) başta olumlu sonra olumsuz bilgiler, ii) başta olumsuz sonra olumlu bilgiler ve iii) başta olumlu bilgiler sonra olumsuz bilgiler sonra da olumlu bir paragraf olmak üzere üç gruba ayrılmıştır ve rastgele öğrencilere verilmiştir. Anketlerin üç formatı aşağıdaki gösterilmiştir:

Şekil 2. Anket Grupları.



\subsection{Yöntem}

Katılımcıların sayısı 200'e ulaştığında güvenilirlik analizi yapılmıştır. Öğrencilerin sorulara verdiği cevapların frekans ve yüzde dağılımları bulunmuştur. Sonra da, 3 grup arasında istatistiki olarak anlamlı bir fark olup olmadığı için parametrik olmayan Mann- Whitney U Test'i uygulanmıştır. Bu testin yapılma nedeni ise, verilerin normal dağılım göstermediklerindendir (Hellmann vd., 2017: 8).

Çalışmada, bilgilerin sıralanması ve grafik gösterimi olmak üzere iki bağımsız değişken, profesyonel olmayan yatırımcıların kararı ise tek bağımlı değişken bulunmaktadır. Katılımcılar rastgele olarak gerçek bir şirkete dayanan farazi bir faaliyet raporu içeren 3 formatın bir tanesine yönlendirilmiştir. Cevaplar ve görüşlerin objektif olmak amacıyla, şirketin unvanı gizlenmiş ve anketi doldurmasında katılımcılara belirli bir süre verilmemiştir. Anket sorularını hazırlama sürecinde Agnew (2016) çalışmasından yararlanmıştır.

\subsubsection{Hipotezler}

Araştırmanın temel aldığı hipotezlerin beş soruya cevap vermesi beklenmektedir:

Şirketlerin yayınladığı faaliyet raporlarında, 1) metin sıralamasının değişmesine göre veya 2) grafiğgin bulunup bulunmamasina göre;

a) Yatırımcı tarafından incelenen şirketin faaliyetleri hakkında oluşturulan genel görüş değişir mi?

b) Yatırım miktarı değişir mi?

c) Şirkete yapılacak yatırımdan beklenen risk değişir mi?

d) Yatırım kararı üzerinde bir etki oluşur mu?

e) Şirkete yapılacak yatırımdan beklenen kâr oranı etkilenir mi? 
Buna göre, çalışmada on hipotez bulunmaktadır;

$\boldsymbol{H}_{1 a}$ : Olumsuz bilgilerin ardından olumlu bilgileri (grup 3) gören yatırımcılar ile, sıralamanın tersini (grup1) gören yatırımcılar arasında şirketin faaliyetlerini değerlendirme açısından olumlu farklılık bulunmaktadır.

$\boldsymbol{H}_{l b}$ : Olumsuz bilgilerin ardından olumlu bilgileri (grup 3) gören yatırımcılar ile, sıralamanın tersini (grup1) gören yatırımcılar arasında yatırım miktarı açısından olumlu farklılık bulunmaktadır.

$\boldsymbol{H}_{1 c}$ : Olumsuz bilgilerin ardından olumlu bilgileri (grup 3) gören yatırımcılar ile, sıralamanın tersini (grup1) gören yatırımcılar arasında şirkete yapılacak yatırımın risk taşıması değerlendirmesinde olumlu farklılık bulunmaktadir.

$\boldsymbol{H}_{\boldsymbol{l d}}$ : Olumsuz bilgilerin ardından olumlu bilgileri (grup 3) gören yatırımcılar, sıralamanın tersini (grup1) gören yatırımcılardan yatırım kararı konusunu kabul etmeye daha eğilimlidir.

$\boldsymbol{H}_{1 e}$ : Olumsuz bilgilerin ardından olumlu bilgileri (grup 3) gören yatırımcılar ile, siralamanın tersini (grup1) gören yatırımcılar arasında, şirkete yapılacak yatırımın diğer finansal araçlara göre daha fazla kâr edebileceği ifadesine katılma düzeyleri arasında olumlu farklılık bulunmaktadır.

$\boldsymbol{H}_{2 a}$ : Olumlu bilgiler- olumsuz bilgiler sıralamasından sonra, olumlu bir grafik (grup 2) gören yatırımcilar ile, aynı sıralamayı ancak grafik olmadan gören yatırımcı (grup 1) arasında şirketin faaliyetlerini değerlendirme açısından olumlu farklılık bulunmaktadır.

$\boldsymbol{H}_{2 b}$ : Olumlu bilgiler- olumsuz bilgiler sıralamasından sonra, olumlu bir grafik (grup 2) gören yatırımcılar ile, aynı sıralamayı ancak grafik olmadan gören yatırımcı (grup 1) arasında yatırım miktarı açısından olumlu farklılık bulunmaktadır.

$\boldsymbol{H}_{2 c}$ : Olumlu bilgiler- olumsuz bilgiler sıralamasından sonra, olumlu bir grafik (grup 2) gören yatırımcılar ile, aynı sıralamayı ancak grafik olmadan gören yatırımcıdan (grup 1) şirkete yapılacak yatırımın risk taşıması değerlendirmesinde olumlu farklılık bulunmaktadır.

$\boldsymbol{H}_{2 d}$ : Olumlu bilgiler- olumsuz bilgiler sıralamasından sonra, olumlu bir grafik (grup 2) gören yatırımcılar, aynı sıralamayı ancak grafik olmadan gören yatırımcılardan (grup 1) yatırım kararı konusunu kabul etmeye daha eğilimlidir.

$\boldsymbol{H}_{2 e}$ : Olumlu bilgiler- olumsuz bilgiler sıralamasından sonra, olumlu bir grafik (grup 2) gören yatırımcılar, aynı sıralamayı ancak grafik olmadan gören yatırımcılara göre (grup 1), şirkete yapılacak yatırımın diğer finansal araçlara göre daha fazla kâr edebileceği ifadesine katılma düzeyleri arasında olumlu farklılık bulunmaktadir.

\section{Şekil 3. Çalışmada kullanılan değişken ve hipotezler}

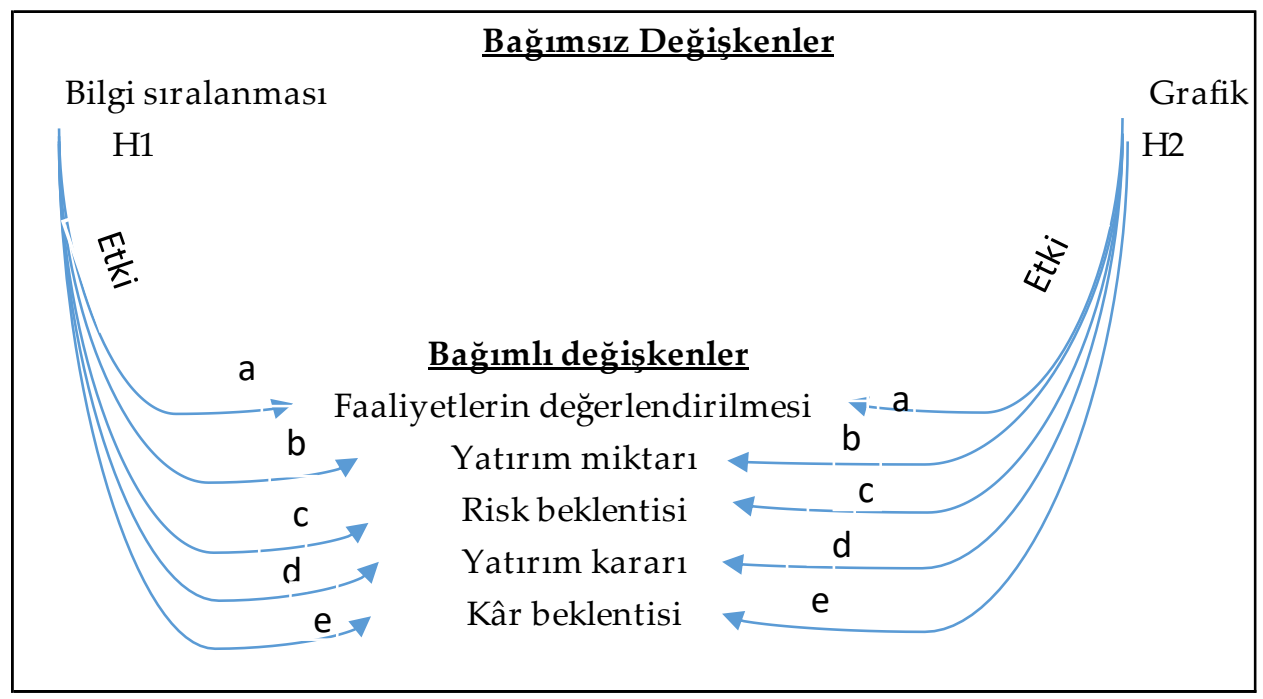

Bu hipotezlerin istatistiki anlamlılığı, İIBF $(A)^{3}$, Bankacıllk ve Finans, Issletme, Maliye, İktisat, İIBF $(B)^{4}$ ve $\dot{I} I B F$ dışı 7 bölüm olmak üzere tek tek analiz edilmiştir.

\footnotetext{
${ }^{3}$ (Bankacılık ve Finans, İşletme, Maliye ve İktisat)

${ }^{4}$ (Uluslararası İlişkiler, Ekonometri, Siyaset Bil. Kamu Yönetimi, Çalışma Ekonomisi ve Endüstri İlişkileri, Sağlık Yönetimi, Turizm İşletmeciliği ve Sosyal Hizmet)
} 


\subsection{Araştırma Bulguları}

\subsubsection{Katılımcıların Demografik Bilgileri}

Aynı amaçla yapılacak ikinci bir ölçümde aynı sonuçların elde edileceğine güven duyulması gereklidir Araştırmada kullanılan ölçeğin güvenilirliğini tespit etme amacı ile, güvenilirlik analizi yapılmıştır. Ve alfa katsayıs1 (Cronbach alpha) 0,729 olarak hesaplanmıştır. Ölçeğin güvenilirliği, araştırmanın benimsediği amaçla yapılacak ikinci bir ölçümde aynı sonuçların elde edilebileceği anlamına gelir. Alfa $(\alpha)$ katsayı 0.60 ile 0.80 arasında olması, ölçek oldukça güvenilir anlamına gelir (Kayış, 2014: 405; Kılıç, 2016). Aşağıdaki tablolarda katılımcıların demografik özellikleri yer almaktadır.

Tablo 3. Anket Gruplarının Cinsiyete Göre Dağılımı

\begin{tabular}{|l|l|l|l|l|l|l|}
\hline Grup & Kadın & $\boldsymbol{\%}$ (Yatay) & Erkek & $\boldsymbol{\%}$ (Yatay) & Katılımcı sayıs & \% (Dikey) \\
\hline+- & 69 & $\% 56.6$ & 53 & $\% 43.4$ & 122 & $\% 29$ \\
\hline+- Grafik & 73 & $\% 57.0$ & 55 & $\% 43.0$ & 128 & $\% 30$ \\
\hline-+ & 112 & $\% 65.1$ & 60 & $\% 34.9$ & 172 & $\% 41$ \\
\hline Toplam & $\mathbf{2 5 4}$ & $\mathbf{\% 6 0 . 2}$ & $\mathbf{1 6 8}$ & $\mathbf{\% 3 9 . 8}$ & 422 & $\% 100$ \\
\hline
\end{tabular}

Ankete katılanların \%39,8'ini erkekler ve \%60,2'sini kadınlar oluşturmaktadır. Ankete katılanların $\% 87,9$ 'u 18 ile 25 yaşında, \%11.1'i 26 ile 33 yaş aralığındadır.

Tablo 4. Araştırmaya Katılan Öğrencilerin Anket Gruplarına Göre Eğitim Seviyeleri

\begin{tabular}{|l|l|l|l|l|l|l|}
\hline \multicolumn{2}{|c|}{} & \multicolumn{2}{l|}{ Eğitim Seviyesi } & \multirow{2}{*}{$\%$} \\
\cline { 3 - 6 } \multicolumn{2}{|c|}{} & Lisans & Yüksek Lisans & Doktora & \multirow{2}{*}{ Toplam } & \\
\hline \multirow{3}{*}{ Anket Grubu } & +- & 104 & 15 & 3 & 122 & $\% 29$ \\
\cline { 2 - 6 } & +- Grafik & 102 & 24 & 1 & 127 & $\% 30$ \\
\cline { 2 - 6 } & -+ & 157 & 11 & 4 & 172 & $\% 41$ \\
\hline Toplam & 363 & 50 & 8 & 421 & $\% 100$ \\
\hline$\%$ & $\% 86$ & $\% 12$ & $\% 2$ & & \\
\hline
\end{tabular}

Çalışmaya lisans eğitiminin üçüncü ve dördüncü sınıfına devam eden 363, yüksek lisanstan 50, ve doktora öğrencilerinden 8 öğrenci katılmıştır.

Tablo 5. Araştırmaya Katılan Öğrencilerin Finansal Okuryazarlığı İle İlgili Bulgular

\begin{tabular}{|c|c|c|c|c|c|}
\hline & & & \multicolumn{2}{|c|}{ Cinsiyet } & \multirow[t]{2}{*}{ Toplam } \\
\hline & & & Erkek & Kadın & \\
\hline \multirow{4}{*}{$\begin{array}{l}\text { Derslerinize ilave olarak muhasebecilik, } \\
\text { yatırım, finans kurslarına katıldınız mı? }\end{array}$} & \multirow[t]{2}{*}{ Evet } & Frekans & 29 & 34 & 63 \\
\hline & & $\%$ & 17.3 & 13.4 & 14.9 \\
\hline & \multirow[t]{2}{*}{ Hayır } & Frekans & 139 & 220 & 359 \\
\hline & & $\%$ & 82.7 & 86.6 & 85.1 \\
\hline \multirow{8}{*}{$\begin{array}{l}\text { Ne sıklıkla faaliyet raporları } \\
\text { inceliyorsunuz? }\end{array}$} & \multirow[t]{2}{*}{ Çok Sık } & Frekans & 4 & 7 & 11 \\
\hline & & $\%$ & 2.5 & 2.8 & 2.7 \\
\hline & \multirow[t]{2}{*}{ Sık } & Frekans & 35 & 53 & 88 \\
\hline & & $\%$ & 21.5 & 21.2 & 21.3 \\
\hline & \multirow[t]{2}{*}{ Nadiren } & Frekans & 47 & 59 & 106 \\
\hline & & $\%$ & 28.8 & 23.6 & 25.7 \\
\hline & \multirow[t]{2}{*}{ Hiç } & Frekans & 77 & 131 & 208 \\
\hline & & $\%$ & 47.2 & 52.4 & 50.4 \\
\hline \multirow{2}{*}{$\begin{array}{l}\text { Ne siklıkla finansal tabloları } \\
\text { inceliyorsunuz? }\end{array}$} & \multirow[t]{2}{*}{ Çok Sık } & Frekans & 9 & 2 & 11 \\
\hline & & $\%$ & 5.5 & .8 & 2.7 \\
\hline
\end{tabular}




\begin{tabular}{|c|c|c|c|c|c|}
\hline & \multirow[t]{2}{*}{ Sık } & Frekans & 53 & 65 & 118 \\
\hline & & $\%$ & 32.1 & 26.3 & 28.6 \\
\hline & \multirow[t]{2}{*}{ Nadiren } & Frekans & 45 & 60 & 105 \\
\hline & & $\%$ & 27.3 & 24.3 & 25.5 \\
\hline & \multirow[t]{2}{*}{ Hiç } & Frekans & 58 & 120 & 178 \\
\hline & & $\%$ & 35.2 & 48.6 & 43.2 \\
\hline \multirow{4}{*}{$\begin{array}{l}\text { Temel analiz hakkında bir fikriniz var } \\
\text { mı? }\end{array}$} & \multirow[t]{2}{*}{ Evet } & Frekans & 89 & 114 & 203 \\
\hline & & $\%$ & 53.0 & 45.2 & 48.3 \\
\hline & \multirow[t]{2}{*}{ Hayır } & Frekans & 79 & 138 & 217 \\
\hline & & $\%$ & 47.0 & 54.8 & 51.7 \\
\hline \multirow{4}{*}{$\begin{array}{l}\text { Teknik analiz hakkında bir fikriniz var } \\
\text { mı? }\end{array}$} & \multirow[t]{2}{*}{ Evet } & Frekans & 75 & 114 & 189 \\
\hline & & $\%$ & 44.9 & 45.2 & 45.1 \\
\hline & \multirow[t]{2}{*}{ Hayır } & Frekans & 92 & 138 & 230 \\
\hline & & $\%$ & 55.1 & 54.8 & 54.9 \\
\hline \multirow{4}{*}{$\begin{array}{l}\text { Daha önce bir hisse senedi alım-satımı } \\
\text { yaptınız mı? }\end{array}$} & \multirow[t]{2}{*}{ Evet } & Frekans & 63 & 68 & 131 \\
\hline & & $\%$ & 37.5 & 26.9 & 31.1 \\
\hline & \multirow[t]{2}{*}{ Hayır } & Frekans & 105 & 185 & 290 \\
\hline & & $\%$ & 62.5 & 73.1 & 68.9 \\
\hline \multirow{4}{*}{$\begin{array}{l}\text { Şirketlerin haberlerini, hisse senedi } \\
\text { fiyatlarını vs. takip etmek için KAP, } \\
\text { Mynet Finans vb. siteleri inceliyor } \\
\text { musunuz? }\end{array}$} & \multirow[t]{2}{*}{ Evet } & Frekans & 95 & 139 & 234 \\
\hline & & $\%$ & 56.5 & 55.2 & 55.7 \\
\hline & \multirow[t]{2}{*}{ Hayır } & Frekans & 73 & 113 & 186 \\
\hline & & $\%$ & 43.5 & 44.8 & 68.9 \\
\hline
\end{tabular}

Finansal okuryazarlık durumu ile ilgili bilgilerin yer aldığı Tablo 5 'ten de görüleceği üzere ankete katılanlarının \%14.9'u, muhasebe, yatırım ve finans kurslarının en az birine üniversitede gördüğü derslere ilave olarak katılmıştır. Üniversitede gördüğü dersler hariç, erkeklerin \%17.3’ü muhasebe, yatırım ve finans kurslarından en az bir tanesine katılmıştır. Kadınların ise \%13.4'üdür. Ankete katılan öğrencilerin yılda bir inceleyen oranı \%25,7 olmuştur. Öğrencilerin \%50,4'ü farklı sıklıklarda faaliyet raporlarını incelediklerini belirtmiş̧lerdir. Kadınların \%52,4'ü faaliyet raporları hiç incelememişken, erkeklerde bu oran \%47,2'dir.. Çalışmaya katılan öğrencilerin \% 56,8'i finansal tabloları incelemektedir. Erkeklerin \% 64,8'i, kadınların ise 51,4'ü finansal tabloları incelemektedir. Temel analiz ile teknik analiz hakkında erkeklerin sirasıyla \%53'ü ile $\% 44,9$ 'u, kadınların ise \%45,2'si ile \%45,2'si olmak üzere, tüm öğrencilerin \%48,3'ü ile 45,1'si bilgiye sahiptir. Erkeklerin \%37,5'i hisse senedi alım satımı tecrübesine sahipken kadınların sadece \%26,9'u hisse senedi alıp satmıştır.

Çalışma kapsamındaki hipotezleri test etmeden önce veri setinin normal dağılım gösterip göstermediği incelenmiştir.

$\mathrm{H}_{0}$ : veriler normal dağılmaktadır.

$\mathrm{H}_{I}$ : veriler normal dağılmamaktadır.

Olasılık (significant) değerlerinin bulunduğu tabloda, bu değerlerinin her biri, 0,05'den küçük olduğuna göre (\%5 anlamlılık düzeyinde), veriler normal dağılım göstermemektedir. Buna göre, $\mathrm{H}_{0}$ reddedilmiştir. $\mathrm{H}_{1}$ ise reddedilememiştir. Veriler normal dağılmadığından dolayı, parametrik olmayan testler kullanılmalıdır.

Tablo 6. Normallik Testi

\begin{tabular}{|l|r|r|r|r|r|c|}
\hline & \multicolumn{3}{|c|}{$\begin{array}{c}\text { Kolmogorov- } \\
\text { Smirnov }\end{array}$} & \multicolumn{3}{|c|}{ Shapiro-Wilk } \\
\cline { 2 - 7 } & Statistic & df & Sig. & Statistic & df & Sig. \\
\hline İncelediğim şirketin faaliyetlerini olumlu değerlendirmekteyim: & .277 & 54 & .000 & .864 & 54 & .000 \\
\hline $\begin{array}{l}\text { Elimde 10,000 TL'lik bir fon olduğu varsayıldı̆̆ında, bu şirkete } \\
\text { yatıım yapardım: }\end{array}$ & .222 & 54 & .000 & .907 & 54 & .001 \\
\hline
\end{tabular}




\begin{tabular}{|l|r|r|r|r|r|r|}
\hline $\begin{array}{l}\text { Elimde 10,000 TL'lik bir fon olduğu varsayıldı̆̆ında, sermayemin } \\
\text { (.............) TL'sini yatırım yapardım: }\end{array}$ & .246 & 54 & .000 & .828 & 54 & .000 \\
\hline $\begin{array}{l}\text { Bu şirketin hisse senedi satın alınarak yapılacak yatırımın yüksek } \\
\text { risk taşıdığını düşünüyorum: }\end{array}$ & .188 & 54 & .000 & .912 & 54 & .001 \\
\hline $\begin{array}{l}\text { Bu şirketin hisse senedi alınarak yapılacak bir yatııımdan diğer } \\
\text { finansal yatırım araçlarına göre daha fazla kar elde edebilirim: }\end{array}$ & .214 & 54 & .000 & .907 & 54 & .001 \\
\hline
\end{tabular}

a. Lilliefors Significance Correction

Gruplar arasındaki farklılıkların istatistiki olarak anlamlılığını test etmek için, parametrik olmayan MannWhitney U Test'i \%5 Anlamlılık düzeyinde incelenmiştir. Parametrik olmayan Mann- Whitney U Test'i, iki bağımsız grup arasındaki farklılıkların istatistiki anlamlılığını tespit etmek için kullanılmaktadır. Bu test uygulanırken iki hipotez test edilmiştir;

$\mathrm{H}_{0}$ : iki örneklem (grup) arasında istatiksel farklı1ık bulunmamaktadır.

$\mathrm{H}_{I}$ : iki örneklem (grup) arasında istatiksel farklılık bulunmaktadır.

Olasıllk değeri (Significant) 0,05 ' eşit veya büyük olduğunda $\mathrm{H}_{0}$ reddedilemez ve istatistiki olarak farklılıklar bulunmamaktadır. Significant değeri 0,05'ten küçük olduğu durumda ise, $\mathrm{H}_{1}$ kabul edilir ve $\mathrm{H}_{0}$ reddedilir. Bu, farklılıkların istatistiki olarak anlamlı olduğunu ifade eder. İstatistiki olarak anlamlı olan bir sonuç, tesadüfe bağl1 olmayan bir sonuç olduğu anlamına gelir. (Demirgil, 2014: 99; Guarino, 2017; Lane, 2019; Sauro, 2014).

Tablo 7'de test edilen hipotezlerden bulunan olasılık değerlerinden, finansal tabloların incelenmesi ile hisse senedi alım ve/veya satımında tecrübe alanlarında farkların istatistiki olarak anlamlı olduğu anlaşılmaktadır. Başka bir ifade ile finansal tabloların incelenmesi ile hisse senedi alım ve/veya satımı sorularına verilen cevaplar, cinsiyete göre istatistiki olarak farklılıklar anlamlıdır.

Tablo 7. Cinsiyete Göre Öğrencilerin Finansal Okuryazarlık Bilgi İle İlişkisi Sonuç Tablosu MannWhitney U Test Sonuçları

\begin{tabular}{|c|c|c|c|c|c|}
\hline Soru & $\begin{array}{l}\text { Mann- } \\
\text { Whitney U }\end{array}$ & Wilcoxon W & $\mathrm{Z}$ & Sig. & $\begin{array}{l}\text { Hipotez } \\
\left(\mathrm{H}_{0}\right)\end{array}$ \\
\hline $\begin{array}{l}\text { Derslerinize ilave olarak muhasebecilik, yatırım, } \\
\text { finans kurslarına katıldınız mı? }\end{array}$ & 20509.000 & 52894.000 & -1.092 & $0.275^{*}$ & Kabul \\
\hline Ne sıklıkla faaliyet raporları inceliyorsunuz? & 19599.500 & 50974.500 & -0.711 & $0.477 *$ & Kabul \\
\hline Ne sıklıkla finansal tabloları inceliyorsunuz? & 17048.500 & 47676.500 & -2.998 & 0.003 & Ret \\
\hline $\begin{array}{l}\text { Şirketlerin haberlerini, hisse senedi fiyatlarını vs. } \\
\text { takip etmek için KAP, Mynet Finans vb. siteleri } \\
\text { inceliyor musunuz? }\end{array}$ & 20874.000 & 52752.000 & -0.280 & $0.779 *$ & Kabul \\
\hline Temel analiz hakkında bir fikriniz var mı? & 19530.000 & 51408.000 & -1.553 & $0.120 *$ & Kabul \\
\hline Teknik analiz hakkında bir fikriniz var mı? & 20973.000 & 35001.000 & -0.066 & $0.947 *$ & Kabul \\
\hline $\begin{array}{l}\text { Daha önce bir hisse senedi alım-satımı yaptınız } \\
\text { mı? }\end{array}$ & 18994.500 & 51125.500 & -2.303 & 0.021 & Ret \\
\hline
\end{tabular}

a. Grouping Variable: Cinsiyet

*Mann-Whitney U testine göre olasılık değeri $>0,05 * \mathrm{H}_{0}$ hipotezi kabul edilmektedir.

Araştırmanın devamında İktisadi ve İdari Bilimler Fakültesi öğrencisi olup olmama ile finansal okuryazarlık üzerindeki etkisi de araştırılmıştır; i) katılımcılar, İktisadi ve İdari Bilimler Fakültesinde Eğitim Gören (359 öğrenci) ile İktisadi ve İdari Bilimler Fakültesinde Eğitim Görmeyen (62 öğrenci) iki bağımsız grup olarak ayrılırmıştır, ii) bu iki eğitim fakültesi grubu üzerinde Mann- Whitney U test'i uygulanmıştır.

Tablo 8`de sıra ortalamaları Sıra Ortalaması sütunundaki yer alan veriler, İ̈BF öğrencileri ile İIBB öğrencisi olmayan katılımcıların iki grup arasında farklılıkların olduğunu göstermektedir. Ayrıca, bu sonuçlar, İİBF dışında eğitim gören öğrencilerde, İIBF'de okuyanlara nazaran daha düşük çıkmıştır, buradan, İIBF öğrencisi olmayanların, olumsuz seçenekleri büyük oranda seçtiklerini göstermektedir (IÏBF dışı için, tüm sorularda sıra ortalamaları sayısı daha azdır). 
Tablo 8. Eğitim Dalına Göre Finansal Okuryazarlık Cevaplarının Sıra Ortalamaları

\begin{tabular}{|c|c|c|c|c|}
\hline & Eğitim Dalı & $\mathrm{N}$ & $\begin{array}{c}\text { Sira } \\
\text { Ortalamaları } \\
\end{array}$ & $\begin{array}{l}\text { Siraların } \\
\text { Toplamı }\end{array}$ \\
\hline \multirow{3}{*}{$\begin{array}{l}\text { Derslerinize ilave olarak muhasebecilik, yatırım, finans kurslarına } \\
\text { katıldınız mı? }\end{array}$} & İİBF & 359 & 213.51 & 76649.50 \\
\hline & Diğer & 62 & 196.48 & 12181.50 \\
\hline & Toplam & 421 & & \\
\hline \multirow[t]{3}{*}{ Ne sıklıkla faaliyet raporları inceliyorsunuz? } & İ̈BF & 350 & 211.71 & 74098.00 \\
\hline & Diğer & 62 & 177.10 & 10980.00 \\
\hline & Toplam & 412 & & \\
\hline \multirow[t]{3}{*}{ Ne sıklıkla finansal tabloları inceliyorsunuz? } & İ̈̈BF & 349 & 210.30 & 73394.00 \\
\hline & Diğer & 62 & 181.81 & 11272.00 \\
\hline & Toplam & 411 & & \\
\hline \multirow{3}{*}{$\begin{array}{l}\text { Şirketlerin haberlerini, hisse senedi fiyatlarını vs. takip etmek için } \\
\text { KAP, Mynet Finans vb. siteleri inceliyor musunuz? }\end{array}$} & İ̈̈BF & 357 & 220.34 & 78662.50 \\
\hline & Diğer & 62 & 150.44 & 9327.50 \\
\hline & Toplam & 419 & & \\
\hline \multirow[t]{3}{*}{ Temel analiz hakkında bir fikriniz var mı? } & İ̈B̈ & 357 & 222.35 & 79377.50 \\
\hline & Diğer & 62 & 138.91 & 8612.50 \\
\hline & Toplam & 419 & & \\
\hline \multirow[t]{3}{*}{ Teknik analiz hakkında bir fikriniz var mı? } & İ̈̈BF & 356 & 218.91 & 77933.00 \\
\hline & Diğer & 62 & 155.45 & 9638.00 \\
\hline & Toplam & 418 & & \\
\hline \multirow[t]{3}{*}{ Daha önce bir hisse senedi alım-satımı yaptınız mı? } & İ̈BF & 358 & 215.61 & 77110.00 \\
\hline & Diğer & 62 & 182.26 & 11300.00 \\
\hline & Toplam & 420 & & \\
\hline
\end{tabular}

Tablo 9‘da görüleceği üzere, faaliyet raporların incelenmesi, finansal tabloların incelenmesi, borsa haber sitelerin incelenmesi, teknik analiz ile temel analizde bilgiye sahip olması ve hisse senedi alım satımında geçmişe sahip olması soruların cevapları, İktisadi ve İdari Bilimler Fakültesi'nde okuyup okumaya göre bulunan farklılıklar istatistiki olarak anlamlıdır. Muhasebe ve/veya yatırım ve/veya finans alanlarında kursların alınması ise, İ̈BF'de okuyup okumaya göre farklılıklar istatistiki olarak anlamlı değildir.

Tablo 9. İİB'de Okuyup Okumamaya Göre, Öğrencilerin Finansal Okuryazarlık Bilgi İle İlişkisi Sonuç Tablosu Mann-Whitney U Test Sonuçları

\begin{tabular}{|l|r|r|r|r|l|}
\hline Soru & \multicolumn{1}{|l|}{$\begin{array}{l}\text { Mann- } \\
\text { Whitney U }\end{array}$} & Wilcoxon W & Z & $\begin{array}{l}\text { Asymp. } \\
\text { Sig. (2- } \\
\text { tailed) }\end{array}$ & $\begin{array}{l}\text { Hipotez } \\
\left(\mathrm{H}_{0}\right)\end{array}$ \\
\hline $\begin{array}{l}\text { Derslerinize ilave olarak muhasebecilik, yatırım, } \\
\text { finans kurslarına katıldınız mı? }\end{array}$ & 10228.500 & 12181.500 & -1.647 & $.099 *$ & Kabul \\
\hline Ne sıklıkla faaliyet raporları inceliyorsunuz? & 9027.000 & 10980.000 & -2.436 & .015 & Ret \\
\hline Ne sıklıkla finansal tabloları inceliyorsunuz? & 9319.000 & 11272.000 & -2.029 & .042 & Ret \\
\hline $\begin{array}{l}\text { Sirketlerin haberlerini, hisse senedi fiyatlarını vs. } \\
\text { takip etmek için KAP, Mynet Finans vb. siteleri } \\
\text { inceliyor musunuz? }\end{array}$ & 7374.500 & 9327.500 & -4.878 & .000 & Ret \\
\hline Temel analiz hakkında bir fikriniz var mı? & 6659.500 & 8612.500 & -5.785 & .000 & Ret \\
\hline Teknik analiz hakkında bir fikriniz var mı? & 7685.000 & 9638.000 & -4.428 & .000 & Ret \\
\hline $\begin{array}{l}\text { Daha önce bir hisse senedi alım-satımı yaptınız } \\
\text { mı? }\end{array}$ & 9347.000 & 11300.000 & -2.473 & .013 & Ret \\
\hline
\end{tabular}

a. Grouping Variable: Eğitim Dalı

*Mann-Whitney U testine göre olasılık değeri $>0,05 * \mathrm{H}_{0}$ hipotezi kabul edilmektedir. 
Sonuçlar tahlil edildiğinde, beklenen durumu yansıtmaktadır. İİBF'de okumayan öğrencilerin finansal tabloları, faaliyet raporları ve borsa siteleri gibi alanlar hakkında ilgilerinin olması, bu konuları anlamas1 veya tecrübeye sahip olması beklenmezken, kendi bölümünde görmediği muhasebe, finans ve yatırım dersleri ile ilgili kurslara katılması uygun bulunmuştur.

\subsubsection{Tüm Bölümler İçin Hipotezlerin Testi:}

$H_{1 a}, H_{2 a}$ :

Kontrol sorularının incelenmesi neticesinde 24 anket formunda sağlıklı cevap verilmediği tespit edilerek çalışma kapsamına dâhil edilmemiştir. Hipotez (a), olumsuz bilgilerden sonra olumlu bir grafiğgin eklenmesi veya olumlu bilgilerin faaliyet raporunun sonunda bulunması, yatırımcının şirkete oluştuğu görüşün olumlu bir şekilde etkilediği varsayımına dayanır. "İncelediğim şirketin faaliyetlerini olumlu değerlendirmekteyim", sorusunu toplam 412'den 409 öğrenci cevaplamıştır. Grupların arasında farklılıkların daha net görülebilmesi için, her anket grubu için verilen cevapların ortalamalarını hesaplayarak, grafik gösterimi sağlanmıştır. Birinci grupta (olumlu- olumsuz bilgiler) verilen cevapların ortalaması 3.26'dır. Ancak, faaliyet raporun içerdiği bilgilerin sıralanması değiştirildiğinde veya olumlu bilgiler içeren bir grafik bulundurulduğu durumda, bu bilgiler farklı boyutlar görmüştür. Aşağıdaki şekilde görüleceği üzere, $\mathrm{H}_{2 \mathrm{a}}$ hipotezinin tersine, raporun sonunda şirket hakkında olumlu bilgi içeren bir grafik eklendiğinde ortalama 3.21'e düşmüştür. Ayrıca, başta olumsuz bilgi sonda olumlu bilgi sıralaması uygulandığında ve $\mathrm{H}_{1 \mathrm{a}}$ hipotezlerini destekleyerek, bu ortalama 3.49'a artış göstermiştir. Başka bir ifadeyle; faaliyet raporunun son kısmında olumlu bilgiler gören katılımcı, faaliyet raporunun son kısmında olumsuz bilgileri gören katılımcıdan, şirketi olumlu bir şekilde değerlendirmektedir.

\section{Şekil 4. Araştırmaya Katılan Öğrencilerin, Anket Gruplarına Göre Ankette Yer Alan Şirketin Faaliyetleri Değerlendirmeleri}

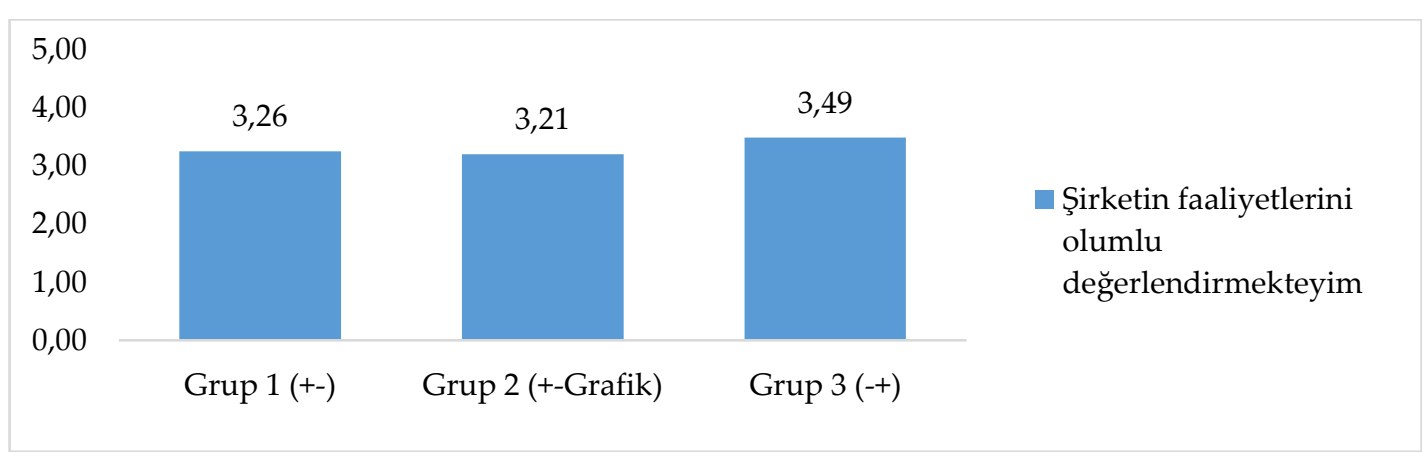

$H_{1 a}$ :

Şekil 4'te yer alan sonucun istatistiksel olarak anlamlı olup olmadığı test edilmiştir. 1. ve 3. grubun arasında istatistiki olarak anlamlı bir fark olup olmadığını tespit etmek için 0,05 anlamlılık düzeyinde Mann- Whitney U Test'i yapılmıştır. Aşağıdaki tabloda, $-1,951$ olarak verilen $z$ değeri ve anlamlılık düzeyi değeri 0,051 olan olasılık değeri bulunmuştur. Olasılık değeri (p) 0,05 'ten büyük olduğuna göre, 1 . ve 3. Grup arasında istatistiki olarak anlamlı farklar bulunmamaktadır ve elde edilen sonuç istatistiki olarak anlamlı değildir. Buna dayanarak, $\mathrm{H}_{I a}$ desteklenmemektedir. Bu sonuca göre, bilgi sıralanmasının değiştirilmesi, yatırımcının şirketi değerlendirmesini veya genel görüşünü etkilememektedir.

$H_{2 a}$ hipotezini test etmek için ise, 1 . ve 2 . Grup üzerine aynı test yapılmıştır ve 1 . ile 2. Grup arasında istatistiki olarak farklar bulunmamaktadır, ( $\mathrm{P}$ değeri 0,796>0,05). Buna göre $\mathrm{H}_{2 a}$ desteklenmemektedir. $\mathrm{Bu}$ bağlamda, olumsuz bilgileri görüp olumsuz görüş oluşturan yatırımcı, olumlu grafikten etki görmemektedir.

Tablo 10. Şirketin Faaliyetlerini Olumlu Değerlendirmekteyim: Anket Gruplarına Göre Verilen Cevapların Arasındaki İstatistiki Anlamlılık Testi

\begin{tabular}{|l|r|l|r|}
\hline \multicolumn{3}{|c|}{$\begin{array}{c}\text { Bu şirketin hisse senedi satın alınarak yapılacak yatırımın yüksek risk } \\
\text { taşıdığını düşünüyorum: }\end{array}$} \\
\hline \multicolumn{2}{|c|}{ 1. ve 3. grup } & \multicolumn{1}{c|}{ 1. ve 2. grup } \\
\hline Mann-Whitney U & 8515.500 & Mann-Whitney U & 7422.000 \\
\hline Wilcoxon W & 15775.500 & Wilcoxon W & 15423.000 \\
\hline Z & -1.951 & Z & -.259 \\
\hline Asymp. Sig. (2-tailed) & .051 & Asymp. Sig. (2-tailed) & .796 \\
\hline
\end{tabular}

a. Grouping Variable: Anket Grubu a. Grouping Variable: Anket Grubu 
$H_{1 b}, H_{2 b}$ :

İkinci hipotez (b), bilgi sunum şekli değişiklerin, yatırımcının şirkete daha fazla para yatırmasına sebep olacaktır. Anket gruplarına göre de, yatırımcının yatırmak istediği miktar da değişmektedir. Aşağıdaki şekilde gösterildiği gibi, olumlu grafik bulunması, yatırımcıların tarafından yatırılacak miktarın ortalaması 2,38'den 2,52'ye yükseldiği, olumlu bilgilerin faaliyet raporunun sonunda yer alması ise bu ortalamayı 2,84'e yükselttiğini görünmektedir.

Şekil 5. Anket Gruplarına Göre Araştırmaya Katılan Öğrencilerin Ankette Yer Alan Şirkete Yatırmak İstedikleri Miktarların Ortalaması

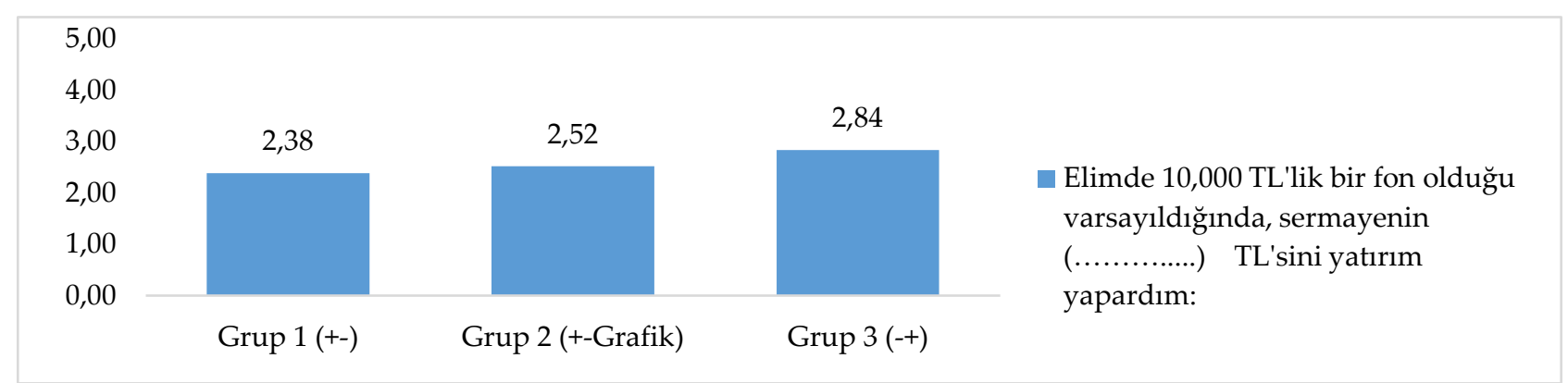

Mann- Whitney U test'i sonuçlarına göre, hipotez $\mathrm{H}_{1 b}$ desteklenmektedir ve $\mathrm{H}_{2 b}$ desteklenmemektedir. $\mathrm{Bu}$ sonuçlar olumlu-olumsuz bilgiler sıralanmasının ters olarak gösterildiğinde, yatırımcı şirkete daha fazla para yatırım yapmak ister anlamına gelir. Olumsuz bilgi ardından olumlu bilgi içeren bir grafiğin bulunmasının etkisi bulunmamaktadır. Mann- Whitney U Test sonuçları aşağıdaki tabloda özetlenmiştir:

Tablo 11. Elimde 10,000 TL'lik Bir Fon Olduğu Varsayıldığında, Sermayemin （.............) TL'sini Yatırım Yapardım: Anket Gruplarına Göre Verilen Cevapların Arasındaki İstatistiki Anlamlılı Testi

\begin{tabular}{|c|c|c|c|}
\hline \multicolumn{4}{|c|}{$\begin{array}{c}\text { Elimde 10,000 TL'lik bir fon olduğu varsayıldığında, sermayemin } \\
(\ldots . . . \ldots \ldots . . . .) \text { TL'sini yatırım yapardım: }\end{array}$} \\
\hline \multicolumn{2}{|c|}{ 1. ve 3. grup } & \multicolumn{2}{|c|}{ 1. ve 2. grup } \\
\hline Mann-Whitney U & 7834 & Mann-Whitney U & 7205.5 \\
\hline Wilcoxon W & 15094 & Wilcoxon W & 14465.5 \\
\hline $\mathrm{Z}$ & -3.594 & $\mathrm{Z}$ & -0.777 \\
\hline Asymp. Sig. (2-tailed) & 0.00 & Asymp. Sig. (2-tailed) & 0.437 \\
\hline
\end{tabular}

$H 1 c, H 2 c$ :

' 'Şirkete yapılacak yatırımın yüksek risk taşıdığını düşünüyorum'” ifadesine, birinci, ikinci ve üçüncü anket grubunu gören yatırımcıların verdiği cevapların ortalamaları sırasıyla, 2.92, 2.80 ve 3.09'dur. Bu sonuçlar, $\mathrm{H}_{2 c}$ hipotezini desteklemekte iken, $\mathrm{H}_{1 c}$ hipotezini desteklememektedir. Aşağıdaki şekilden faaliyet raporlarında bilgi sunum sıralamasında yapılacak değişikliklerin, şirkete yapılacak yatırımın risk taşıyı taşıyamadığı görüşlerini olumsuz bir şekilde etkilediği gözükmektedir. 
Şekil 6. Araştırmaya katılan öğrencilerin ankette yer alan şirkete yapılacak yatırımdan risk beklentilerinin ortalaması

5,00

4,00

3,00

2,92

2,80

2,00

1,00

0,00
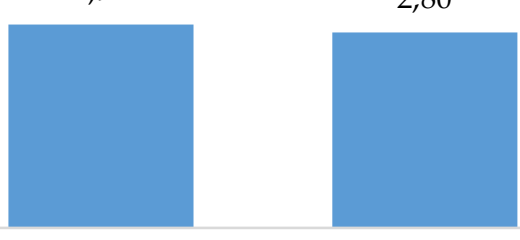

3,09

Grup 1 (+-) Grup 2 (+-Grafik) Grup $3(-+)$

Aşağıdaki tabloda görüleceği üzere olasılık değeri 0.05 'ten büyüktür. Buna göre, $\mathrm{H}_{1 \mathrm{c}}$ ve $\mathrm{H}_{2 \mathrm{c}}$ hipotezleri desteklenmemektedir.

Tablo 12. Bu Şirketin Hisse Senedi Satın Alınarak Yapılacak Yatırımın Yüksek Risk Taşıdığını Düşünüyorum: Anket Gruplarına Göre Verilen Cevapların Arasındaki İstatistiki Anlamlılık Testi

\begin{tabular}{|l|r|l|r|}
\hline \multicolumn{2}{|c|}{ Bu şirketin hisse senedi satın alınarak yapılacak yatırımın yüksek risk } \\
taşıdığını düşünüyorum: \\
\hline 1. ve 3. grup & \multicolumn{2}{c|}{ 1. ve 2. grup } \\
\hline Mann-Whitney U & 9483.500 & Mann-Whitney U & 7128.500 \\
\hline Wilcoxon W & 16743.500 & Wilcoxon W & 15384.500 \\
\hline Z & -1.155 & Z & -1.014 \\
\hline Asymp. Sig. (2-tailed) & .248 & Asymp. Sig. (2-tailed) & .311 \\
\hline
\end{tabular}

a. Grouping Variable: Anket Grubu a. Grouping Variable: Anket Grubu

HId, H2d:

' Elimde 10,000 TL'lik bir fon olduğu varsayıldığında, bu şirkete yatırım yapardım' ifadesine, 419 yanıt verilmiştir ve $\mathrm{H}_{1 \mathrm{c}}$ ile $\mathrm{H}_{2 \mathrm{c}}$ durumunda çıkan sonuçlar aynı yönde gitmiştir. Çalışmaya katılan öğrencilerin \% 65'i yatırım yapmama kararı alırken, kalan \%35'i bu şirkete yatırım yapma kararını almıştır. Olumsuz bilgilerden sonra olumlu bir grafik eklendiğinde, yatırım yapma kararı sorusuna verilen cevapların ortalaması düşüş göstermiş̧ir (3.01 ve 2.98). Üçüncü grubta yer alan katılımcıların yatırım yapma isteğinin yükseldiği görülmektedir (3.01 ve 3.32).

Şekil 7. Araştırmaya Katılan Öğrencilerin Ankette Yer Alan Şirkete Yapılacak Yatırım Kararı Konusunda Yanitların Ortalaması

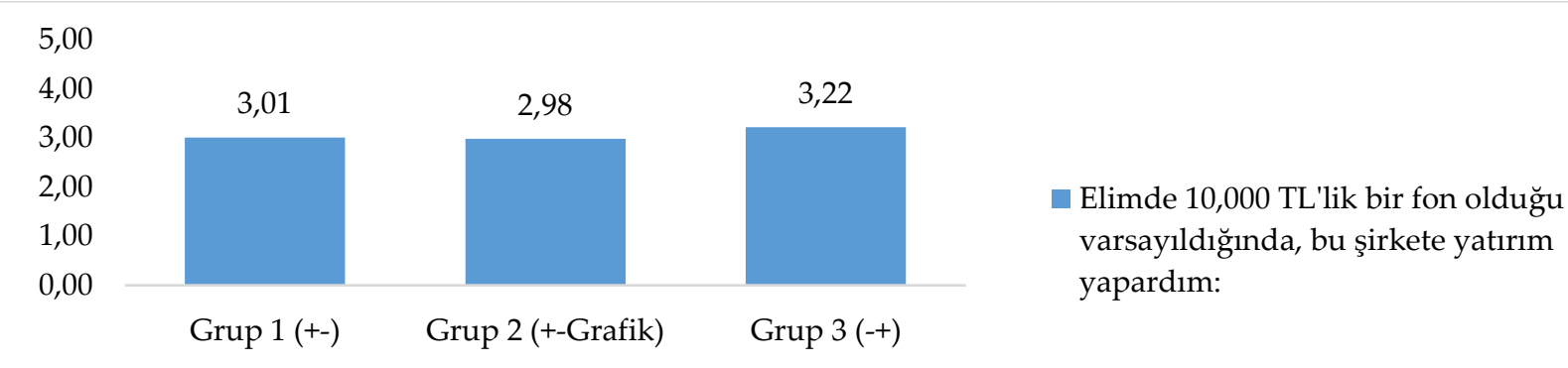


Tablo 13 'te gösterilen sonuçlar, her grup için olasılık değeri 0.05 'ten büyük olduğu için, $\mathrm{H}_{1 \mathrm{~d}}$ ile $\mathrm{H}_{2 \mathrm{~d}}$ hipotezlerini desteklememektedir. Anket grupları arasında istatistiki olarak anlamlı farklıklar bulunmamaktadır.

Tablo 13. Elimde 10,000 TL'lik Bir Fon Olduğu Varsayıldığında, Bu Şirkete Yatırım Yapardım: Anket Gruplarına Verilen Cevapların Arasındaki İstatistiki Anlamlılık

\begin{tabular}{|l|r|l|r|}
\hline \multicolumn{2}{|c|}{ Elimde 10,000 TL'lik bir fon olduğu varsayıldığında, bu şirkete yatırım yapardım: } \\
\hline 1. ve 3. grup & \multicolumn{2}{c|}{ 1. ve 2. grup } \\
\hline Mann-Whitney U & 9208.000 & Mann-Whitney U & 7468.000 \\
\hline Wilcoxon W & 16468.000 & Wilcoxon W & 15596.000 \\
\hline Asymp. Sig. (2-tailed) & -1.643 & Z & -0.283 \\
\hline \\
a Grouping Variable: Anket Grubu & 0.100 & Asymp. Sig. (2-tailed) & 0.777 \\
\hline
\end{tabular}

$H_{1 e}, H_{2 e}$ :

' 'Bu şirketin hisse senedi alınarak yapılacak bir yatırımdan diğer finansal yatırım araçlarına göre daha fazla kâr elde edebilirim" sorusunu toplam 418 öğrenci cevaplamıştır. Çalışma kapsamında araştırılan iki bağımsız değişkenin etkisi, bu soruda yatırımcının fikrini olumlu etkilediğini göstermektedir. Ancak, Grafiğin etkisi istatistiki olarak anlamsız, metin sıralanmasının etkisi istatistiki olarak anlamlı olduğu sonucuna varılmıştır (tablo 14).

\section{Şekil 8. Araştırmaya Katılan Öğrencilerin Ankette Yer Alan Şirkete Yapılacak Yatırımdan Kâr Beklentilerinin Ortalaması}

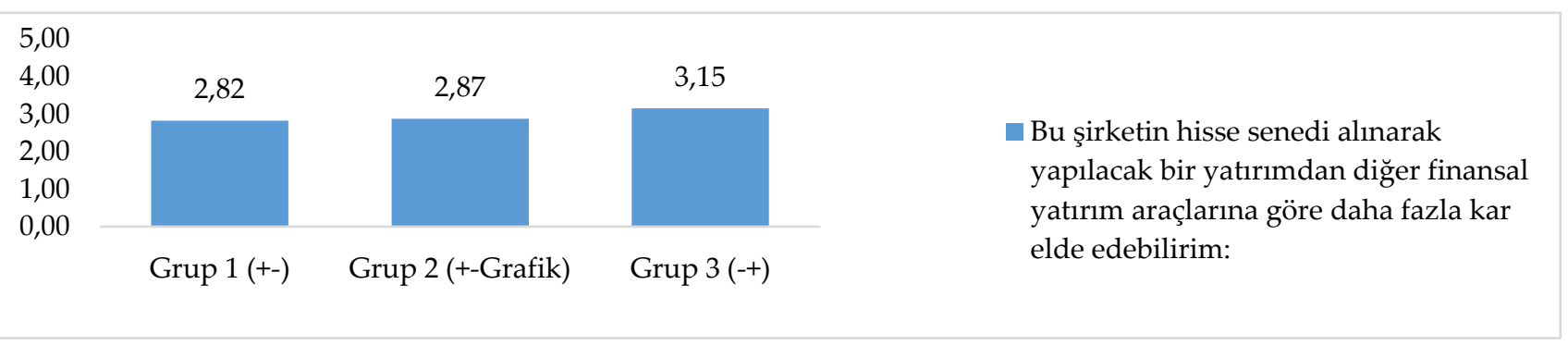

Aşağıdaki tabloda, birinci ve üçüncü grup arasında hesaplanan olasılık değeri $0.006(<0.05)$ olduğu için bu grupların arasındaki farklılıklar istatistiki olarak anlamlıdır. Birinci ve ikinci grup için bulunan olasılık değeri 0.719 (>0.05) farklılıkların istatistiki anlamlı olmadığını göstermekte olup grafiğin bir etkisinin olmadığına işaret etmektedir.

Tablo 14. Bu Şirketin Hisse Senedi Alınarak Yapılacak Bir Yatırımdan Diğer Finansal Yatırım Araçlarına Göre Daha Fazla Kâr Elde Edebilirim: Anket Gruplarına Verilen Cevapların Arasındaki İstatistiki Anlamlılık

\begin{tabular}{|l|l|l|l|}
\hline \multicolumn{3}{|c|}{$\begin{array}{c}\text { Bu şirketin hisse senedi alınarak yapılacak bir yatırımdan diğer finansal } \\
\text { yatırım araçlarına göre daha fazla kâr elde edebilirim: }\end{array}$} \\
\hline \multicolumn{2}{|c|}{ 1. ve 3. grup } & \multicolumn{2}{c|}{ 1. ve 2. grup } \\
\hline Mann-Whitney U & 8476.500 & Mann-Whitney U & 7368.500 \\
\hline Wilcoxon W & 15736.500 & Wilcoxon W & 14628.500 \\
\hline Z & -2.745 & Z & -.360 \\
\hline Asymp. Sig. (2-tailed) & .006 & Asymp. Sig. (2-tailed) & .719 \\
\hline
\end{tabular}

a. Grouping Variable: Anket Grubu a. Grouping Variable: Anket Grubu 
Sonuçlar genel olarak, raporlara grafik eklenmesinin hiçbir etkisinin olmadığını ve bilgi sıralanmanın değiştirilmesinin sadece "yatırımcının yatırmak istediği miktarı" ve "beklenen kârı" olumlu bir şekilde etkilediğini göstermektedir. Sonuçlar aşağıdaki tabloda özetlenmiştir:

Tablo 15. Tüm Veriler: Hipotezlerin Testi (Mann- Whitney U Test)

\begin{tabular}{|c|c|c|c|c|c|c|c|c|c|}
\hline \multirow{3}{*}{\multicolumn{2}{|c|}{ Tüm veriler }} & \multicolumn{8}{|c|}{ Bağımsız Değişkenler } \\
\hline & & \multicolumn{4}{|c|}{ Metin sıralaması $(1,3)$} & \multicolumn{4}{|c|}{ Olumlu grafik $(1,2)$} \\
\hline & & Sig. & $\begin{array}{l}\text { Hipotez } \\
\left(\mathrm{H}_{0}\right)\end{array}$ & Etkisi & Yönü & Sig. & $\begin{array}{l}\text { Hipotez } \\
\left(\mathrm{H}_{0}\right)\end{array}$ & Etkisi & Yönü \\
\hline \multirow{5}{*}{ 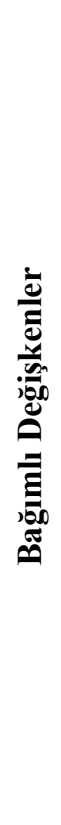 } & $\begin{array}{l}\text { İncelediğim şirketin } \\
\text { faaliyetlerini olumlu } \\
\text { değerlendirmekteyim: }\end{array}$ & $0.510 *$ & Kabul & Yok & & $0.796^{*}$ & Kabul & Yok & \\
\hline & $\begin{array}{l}\text { Elimde } 10,000 \text { TL'lik bir fon } \\
\text { olduğu varsayıldığında, } \\
\text { sermayemin } \quad(\ldots . . . \ldots \ldots . . .) \\
\text { TL'sini yatırım yapardım: }\end{array}$ & 0.000 & Ret & Var & Olumlu & $0.437 *$ & Kabul & Yok & \\
\hline & $\begin{array}{l}\text { Bu şirketin hisse senedi satın } \\
\text { alınarak yapılacak yatırımın } \\
\text { yüksek risk taşıdığını } \\
\text { düşünüyorum: }\end{array}$ & $0.248^{*}$ & Kabul & Yok & & $0.442 *$ & Kabul & Yok & \\
\hline & $\begin{array}{l}\text { Elimde } 10,000 \text { TL'lik bir fon } \\
\text { olduğu varsayıldığında, bu } \\
\text { şirkete yatırım yapardım: }\end{array}$ & $0.100^{*}$ & Kabul & Yok & & $0.777 *$ & Kabul & Yok & \\
\hline & $\begin{array}{l}\text { Bu şirketin hisse senedi } \\
\text { alınarak yapılacak bir } \\
\text { yatırımdan diğer finansal } \\
\text { yatırım araçlarına göre daha } \\
\text { fazla kar elde edebilirim," }\end{array}$ & 0.006 & Ret & Var & Olumlu & $0.719 *$ & Kabul & Yok & \\
\hline
\end{tabular}

Tablo 15 'dan de görüleceği üzere, raporlara grafik eklenmesinin yatırımcı kararlarına istatistiksel olarak anlamlı bir etkisi yoktur ve kullanılan diğer bağımlı değişkenlerden, sadece yatırım miktarı ile beklenen kâr etkilenmektedir. Başka bir ifadeyle, bu iki kararda yenilik etkisi bulunmaktadır. Araştırmanın devamında cinsiyete göre yenilik etkisi incelenmiştir ve sonuçlar, kadın öğrencilerinin bu etkiye duyarlılığını göstermektedir, erkek öğrencilerde bu durum tespit edilememiştir (Tablo 16).

Tablo 16. Tüm Veriler: Cinsiyete Göre Hipotezlerin Testi (Mann- Whitney U Test)








*Mann-Whitney $\mathrm{U}$ testine göre olasilık değeri $>0,05 * \mathrm{H}_{0}$ hipotezi kabul edilmektedir.

Daha önce yapılan çalışmalarda, katılımcının tecrübesi olup olmaması, yenilik etkisini etkilediğini göstermektedir; (Miller ve Krosnick, 1998; Berry, 2015: 1573). Katılımcıların finansal okuryazarlık durumuna göre yenilik etkisi farklı boyutlarda etkilendiği görülmektedir, sonuçları şu şekilde özetlemek mümkündür;

Araştırmaya katılan öğrencilerin 40'1, faaliyet raporları, finansal tabloları, şirketlerin haberlerini incelemek yanında teknik analiz, temel analiz ve hisse senedi alım satımı noktalarında bilgiye sahiptir, bu grup katılımcıya alpha ismi verilmiştir. Bu özelliklerin hiç birine sahip olmayan katılımcı sayısı ise 82 'dir, bu grup katılımcıya beta ismi verilmiştir.

Tablo 17. Finansal Okuryazarlık Durumuna Göre Hipotezlerin Testi

\begin{tabular}{|l|l|l|l|l|l|l|}
\hline & \multicolumn{3}{|c|}{$\begin{array}{c}\text { Alpha (40 } \\
\text { yatırımcı) }\end{array}$} & \multicolumn{3}{c|}{ Beta (82 yatırımcı) } \\
\hline Hipotez & Sig. & Karar & Etki & Sig. & Karar & Etki \\
\hline H1a & 0.837 & Ret & & 0.267 & Ret & \\
\hline H2a & 0.786 & Ret & & 0.687 & Ret & \\
\hline H1b & 0.635 & Ret & & 0.028 & Kabul & Olumlu \\
\hline H2b & 0.063 & Ret & & 0.008 & Kabul & Olumlu \\
\hline H1c & 0.955 & Ret & & 0.042 & Kabul & Olumlu \\
\hline H2c & 0.393 & Ret & & 0.016 & Kabul & Olumlu \\
\hline H1d & 0.635 & Ret & & 0.401 & Ret & \\
\hline
\end{tabular}




\begin{tabular}{|l|l|l|l|l|l|l|}
\hline H2d & 0.786 & Ret & & 0.195 & Ret & \\
\hline H1e & 0.556 & Ret & & 0.194 & Ret & \\
\hline H2e & 0.857 & Ret & & 0.363 & Ret & \\
\hline
\end{tabular}

Tablo 17'den görüleceği üzere, bahsedilen tüm özelliklere sahip olan profesyonel olmayan yatırımcının kararı, hiç etki görmemiştir. Diğer grup ise (beta), yatırım miktarı ve risk beklentisi, hem grafikten hem de bilgi sıralanmasından olumlu olarak (yenilik etkisi) etkilenmiştir.

\subsubsection{Her Bölüm İçin Hipotezlerin Testi:}

Araştırmanın bu safhasında katılımcılar bölüm düzeyinde ele alınarak aynı testler tekrarlanmıştır. Bu ayrım yapılırken İ̈BF bölümlerinden eğitim kapsamında ekonomi ve finans ağırlı̆̆ görece diğer bölümlerden fazla olan dört bölüm(IIIBFA) birlikte ele alınmıştır. Çıkan sonuçların detaylı analizleri için bölümler bazında ayrıca analizler yapılmıştır. Devamında İ̈BF diğer bölümler(İ̈BF B) ve kontrol grubu olan İIBBF dışı bölümler için aynı analiz tekrarlanmıştır.

\subsubsection{1.İIBF (A) (Bankacılık ve Finans, İşletme, İktisat ve Maliye)}

İ̈BF(A)'da eğitim gören katılımcılara yönelik analizden, elde edilen sonuçlar, metin sıralamasının (olumluolumsuza karşı olumsuz-olumlu), yatırım kararını, yatırım miktarını, şirketin riskli olup olmadığı görüşünü ve şirketin faaliyetlerini değerlendirilmesini, olumlu bir şekilde etkilendiğini göstermektedir. İktisadi ve İdari Bilimler Fakültesindeki, İşletme, Bankacılık ve Finans, İktisat ve Maliye bölümünde okuyan katılımcıların yanıtları test edildikten sonra, tüm sorular için grafiğin etkisinin istatistiki olarak anlamsız olduğunu göstermektedir $(\mathrm{P}>0,005)$. Bilgi sıralanmasının değiştirilmesinin ise, şirketin değerlendirilmesi, yatırım kararı, yatırım miktarını ve beklenen kârı etkilerken $(\mathrm{P}<0,05 ; 0,005 / 0,000 / 0,006 / 0,01)$ şirkete yapılacak yatırımdan beklenen riski etkilememektedir $(\mathrm{P}>0,05)$. Sonuçlar, $\mathrm{H}_{l a}, \mathrm{H}_{l b}, \mathrm{H}_{l d}$ ve $\mathrm{H}_{l e}$ desteklemektedir. $\mathrm{H}_{l c}, \mathrm{H}_{2 a}, \mathrm{H}_{2 b}, \mathrm{H}_{2 c}$, $\mathrm{H}_{2 d}$ ve $\mathrm{H}_{2 e}$ ise desteklenmemektedir.

Tablo 18. İİBF (A) Öğrencileri: Hipotezlerin Testi (Mann- Whitney U Test)

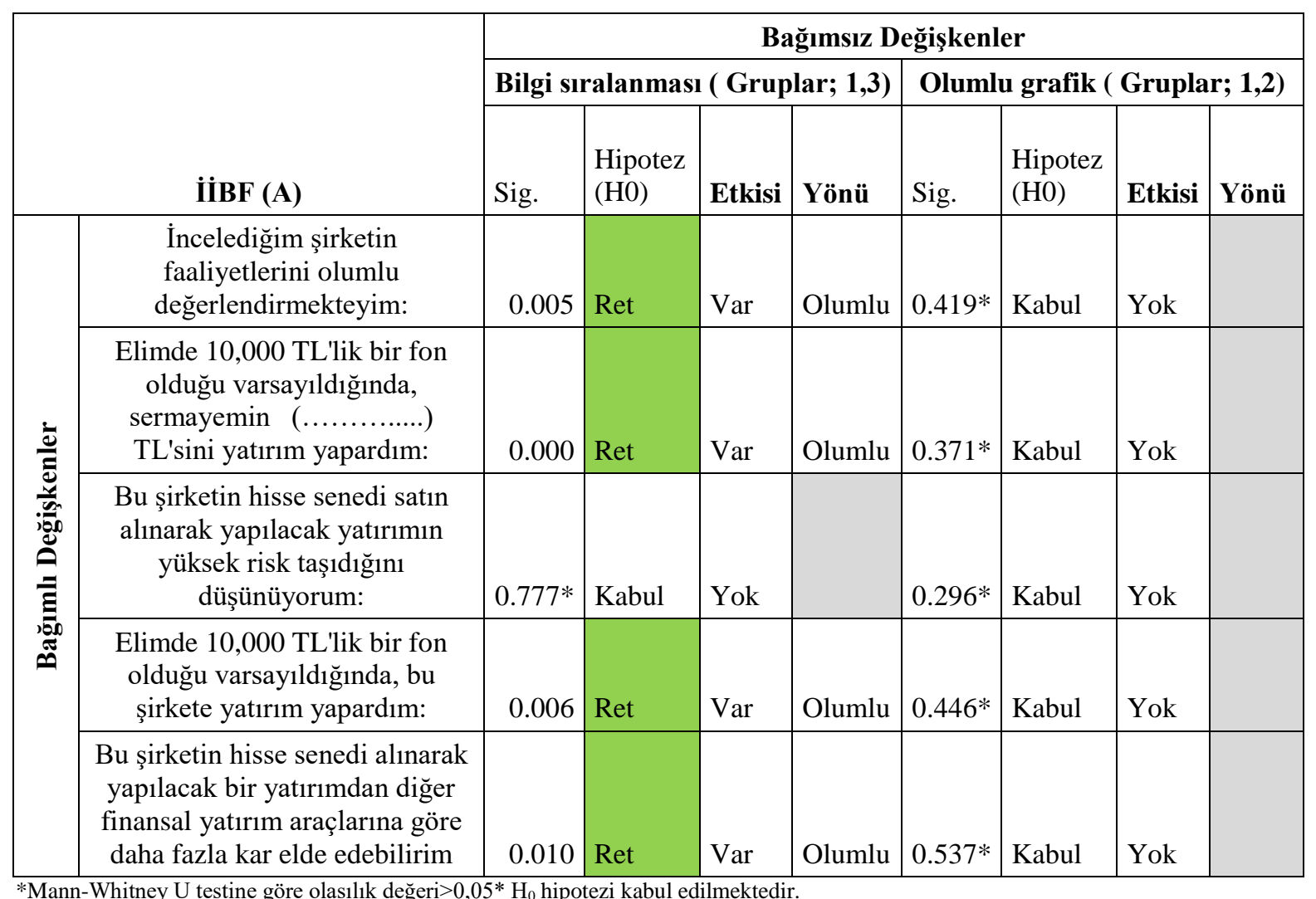


İ̈BF durumunda, yenilik yani yeni bilginin etkisi bulunmuştur. Bu etkinin hangi bölümlerde bulunduğunu bulabilmek için, Bankacılık ve Finans, İşletme, Maliye ve İktisat her bir bölüm için hipotezler test edilmiştir. Bölümler bazında ortalama değişimleri şekil 9-12 arasında yer verilmiştir. Grafiklerdeki sütun açılamaları aşağıdaki gibidir:

\footnotetext{
Elimde 10,000 TL'lik bir fon olduğu varsayıldığında, sermayenin (.............) TL'sini yatırım yapardım:

- Șirketin faaliyetlerini olumlu değerlendirmekteyim

= Elimde 10,000 TL'lik bir fon olduğu varsayıldığında, bu șirkete yatınm yapardım:

Bu șirketin hisse senedi satm almarak yapılacak yatınmm yüksek risk tașığı̆ı düșünüyorum

- Bu șirketin hisse senedi alınarak yapılacak bir yatırımdan diğer finansal yatırım araçlarma göre daha fazla kar elde edebilirim:
} 




Selçuk Üniversitesi Sosyal Bilimler Meslek Yüksekokulu Dergisi, Yıl: 2020 Cilt: 23 Sayı:1 


\section{Bankacllik ve Finans}

Bankacılık ve Finans bölümünde okuyan öğrencilerin verilerinden (şekil 10);

i) yatırım kararı, yatırım miktarı ve kâr beklentisi, hem grafikten hem metin sıralaması değişkeninden olumlu bir şekilde etkilendiği görülmüştür ve

ii) Şirket hakkında oluşturulan görüş ve risk beklentisi ise, grafikten olumsuz, bilgi sıralaması değişimine olumlu etki göstermiştir. Bu farkların istatistiki olarak anlamlılığı test edilmiştir ve anlamlı olmadığı sonucuna varılmıştır (Bankacılık ve Finans ile diğer tüm bölümlerin Mann- Whitney U Test sonuçları, sonuç kısmında yer almaktadır). Bu, Bankacılık ve Finans öğrencileri için tüm hipotezlerin desteklenmediği anlamına gelmektedir. Başka bir ifadeyle, faaliyet raporunda gösterilen grafiklerden ve/veya faaliyet raporundaki bilgilerin sıralanması değişimi, Bankacılık ve Finans bölümü öğrencilerinin yatırım kararlarını hiçbir şekilde etkilememektedir.

\section{İ̧letme}

Araştırmaya İşletme bölümünden 70 öğrenci katılmıştır. Grafiğin ile bilgi sıralanması değişkeni, bu deneklerin yatırmak istedikleri miktarı ve yatırım kararını olumlu bir şekilde etkilemiştir. Olumsuz bilgilerin ardından olumlu bilgi içeren bir grafiğin gösterilmesi, şirketin değerlendirilmesi, risk beklentisini ve kâr beklentisini olumsuz bir şekilde önemli derecede etkilemiştir (risk beklentisi azalmıştır). Ancak, test sonuçlarında hiçbir hipotez desteklenmemiştir(Mann- Whitney U Test sonuçları, sonuç kısmında yer almaktadır).

\section{Maliye}

Maliye bölümü öğrencilerinin cevap ortalamaları sonuçlarına göre tüm bağımlı değişkenlerin bağımsız değişkenlerden olumlu bir şekilde etkilediğini göstermektedir. Aşağıdaki tabloda yer alan Mann - Whitney U test sonuçları, yatırım miktarı ile kâr beklentisinin bilgi sıralanması değişkeninden olumlu bir şekilde etkilendiğini göstermektedir. Buna göre, Maliye bölümü için, $\mathrm{H}_{1 \mathbf{b}}$ ve $\mathrm{H}_{1 \mathbf{e}}$ hipotezleri desteklenmektedir. Diğer hipotezler desteklenmemektedir.

Tablo 19. Maliye Bölümü Öğrencileri: Hipotezlerin Testi (Mann- Whitney U Test)

\begin{tabular}{|c|c|c|c|c|c|c|c|c|c|}
\hline & \multirow[b]{3}{*}{ Maliye } & \multicolumn{8}{|c|}{ Bağımsız Değişkenler } \\
\hline & & \multicolumn{4}{|c|}{$\begin{array}{c}\text { Bilgi sıralanması ( Gruplar; } \\
\qquad 1,3 \text { ) }\end{array}$} & \multicolumn{4}{|c|}{ Olumlu grafik ( Gruplar; 1,2) } \\
\hline & & Sig. & $\begin{array}{c}\text { Hipotez } \\
\text { (H0) }\end{array}$ & Etkisi & Yönü & Sig. & $\begin{array}{c}\text { Hipotez } \\
\text { (H0) }\end{array}$ & Etkisi & Yönü \\
\hline \multirow{5}{*}{ 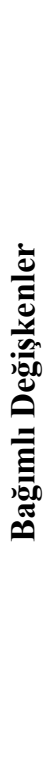 } & $\begin{array}{l}\text { İncelediğim şirketin } \\
\text { faaliyetlerini olumlu } \\
\text { değerlendirmekteyim: }\end{array}$ & $0.113 *$ & Kabul & Yok & & $0.356^{*}$ & Kabul & Yok & \\
\hline & $\begin{array}{l}\text { Elimde } 10,000 \text { TL'lik bir fon } \\
\text { olduğu varsayıldığında, } \\
\text { sermayemin }(\ldots . . . \ldots \ldots . . . .) \\
\text { TL'sini yatırım yapardım: }\end{array}$ & 0.003 & Ret & Var & Olumlu & $0.315^{*}$ & Kabul & Yok & \\
\hline & $\begin{array}{l}\text { Bu şirketin hisse senedi satın } \\
\text { alınarak yapılacak yatırımın } \\
\text { yüksek risk taşıdığını } \\
\text { düşünüyorum: }\end{array}$ & $0.563 *$ & Kabul & Yok & & $0.467 *$ & Kabul & Yok & \\
\hline & $\begin{array}{l}\text { Elimde } 10,000 \text { TL'lik bir fon } \\
\text { olduğu varsayıldığında, bu } \\
\text { şirkete yatırım yapardım: }\end{array}$ & $0.116^{*}$ & Kabul & Yok & & $0.691 *$ & Kabul & Yok & \\
\hline & $\begin{array}{l}\text { Bu şirketin hisse senedi alınarak } \\
\text { yapılacak bir yatırımdan diğer } \\
\text { finansal yatırım araçlarına göre } \\
\text { daha fazla kar elde edebilirim }\end{array}$ & 0.015 & Ret & Var & Olumlu & $0.696^{*}$ & Kabul & Yok & \\
\hline
\end{tabular}

\section{Iktisat}

İktisat bölümünde, grafiğin yatırım miktarı üzerinde bir etkiye sahip olmamakla beraber, kalan tüm bağımlı değişkenler üzerinde olumlu bir etkiye sahip olmuştur. Bilgi sıralanması değiştirilmesi ise, bağımlı değişkenleri olumlu bir şekilde etkilediği görülmektedir. Ancak tüm hipotezlerde olasılık değeri 0,05 'den 
büyük olduğu için, hiçbir hipotez desteklenmemektedir bu bölümün analizinde. (Mann- Whitney U Test sonuçları, sonuç kısmında yer almaktadır).

\subsubsection{IİBF (B)}

Çalışmaya, Bankacılık ve Finans, İşletme, Maliye ve İktisat dışında diğer İİB bölümlerinden katılan öğrencilerin sayısı 62'dir. Bu bölümlerde okuyan öğrencilerin cevaplarının büyük kesimi, bağımsız değişkenlerden olumsuz bir şekilde etkilenmiştir (cevapların sıra ortalamaları eklerde yer almaktadır). Ancak, olasılık değeri ele alındığında sadece grafiğin yatırım kararını olumsuz bir şekilde etkilediği sonucuna ulaşılmıştır. Bu bize, bu yatırımcıların yatırım kararı aldıklarında öncelik etkisini (Primacy effect) yaşadıklarını göstermektedir. Buna göre, $\mathrm{H}_{2 d}$ hariç, hiçbir hipotez desteklenmemektedir.

Tablo 20. Diğer İỉBF Bölümler Öğrencileri: Hipotezlerin Testi (Mann- Whitney U Test)

\begin{tabular}{|c|c|c|c|c|c|c|c|c|c|}
\hline & \multirow[b]{3}{*}{ İ̈BF (B) } & \multicolumn{8}{|c|}{ Bağımsız Değișkenler } \\
\hline & & \multicolumn{4}{|c|}{ Bilgi sıralanması ( Gruplar; } & \multicolumn{4}{|c|}{ Olumlu grafik ( Gruplar; 1,2) } \\
\hline & & Sig. & $\begin{array}{l}\text { Hipotez } \\
\text { (H0) }\end{array}$ & Etkisi & Yönü & Sig. & $\begin{array}{l}\text { Hipotez } \\
\text { (H0) }\end{array}$ & Etkisi & Yönü \\
\hline \multirow{5}{*}{ 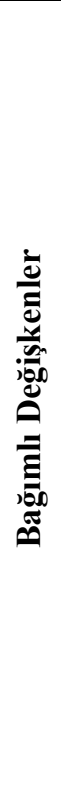 } & $\begin{array}{l}\text { İncelediğim şirketin } \\
\text { faaliyetlerini olumlu } \\
\text { değerlendirmekteyim: }\end{array}$ & $0.568 *$ & Kabul & Yok & & $0.105^{*}$ & Kabul & Yok & \\
\hline & $\begin{array}{l}\text { Elimde 10,000 TL'lik bir fon } \\
\text { olduğu varsayıldığında, } \\
\text { sermayemin (.............) } \\
\text { TL'sini yatırım yapardım: }\end{array}$ & $0.851^{*}$ & Kabul & Yok & & $0.792 *$ & Kabul & Yok & \\
\hline & $\begin{array}{l}\text { Bu şirketin hisse senedi satın } \\
\text { alınarak yapılacak yatırımın } \\
\text { yüksek risk taşıdığını } \\
\text { düşünüyorum: }\end{array}$ & $0.236 *$ & Kabul & Yok & & $0.414 *$ & Kabul & Yok & \\
\hline & $\begin{array}{l}\text { Elimde } 10,000 \text { TL'lik bir fon } \\
\text { olduğu varsayıldığında, bu } \\
\text { şirkete yatırım yapardım: }\end{array}$ & $0.708 *$ & Kabul & Yok & & 0.039 & Ret & Var & Olumsuz \\
\hline & $\begin{array}{l}\text { Bu şirketin hisse senedi alınarak } \\
\text { yapılacak bir yatırımdan diğer } \\
\text { finansal yatırım araçlarına göre } \\
\text { daha fazla kar elde edebilirim }\end{array}$ & $0.573 *$ & Kabul & Yok & & $0.229 *$ & Kabul & Yok & \\
\hline
\end{tabular}

*Mann-Whitney U testine göre olasılık değeri $>0,05^{*} \mathrm{H}_{0}$ hipotezi kabul edilmektedir.

\subsubsection{IIIBF dışı}

Araştırmaya İktisadi ve İdari Bilimler Fakültesinde okumayan 62 öğrenci katılmıştır. Bu öğrencilerin cevaplarından elde edilen sıra ortalamaları, grafik ile bilgi sıralanmasının değiştirilmesinin, öğrencilerin fikirlerini çeşitli yönlerde etkilediğini göstermektedir (sıra ortalamaları ektedir). Mann- Whitney U Test'inde olasılık değeri, İIBF dışında okuyan öğrenciler için tüm hipotezlerin desteklenmediğini göstermektedir.

Tablo 21. İIBF Dışı Bölümler Öğrencileri: Hipotezlerin Testi (Mann- Whitney U Test)

\begin{tabular}{|c|c|c|c|c|c|c|c|c|}
\hline \multirow[b]{3}{*}{ İiBF dışı } & \multicolumn{8}{|c|}{ Bağımsız Değişkenler } \\
\hline & \multicolumn{4}{|c|}{ Bilgi suralanması ( Gruplar; 1,3) } & \multicolumn{4}{|c|}{ Olumlu grafik ( Gruplar; 1,2) } \\
\hline & Sig. & $\begin{array}{l}\text { Hipotez } \\
\text { (H0) }\end{array}$ & Etkisi & Yönü & Sig. & $\begin{array}{l}\text { Hipotez } \\
\text { (H0) }\end{array}$ & Etkisi & Yönü \\
\hline 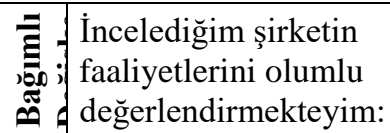 & $0.847 *$ & Kabul & Yok & & $0.385^{*}$ & Kabul & Yok & \\
\hline
\end{tabular}




\begin{tabular}{|c|c|c|c|c|c|c|}
\hline $\begin{array}{l}\text { Elimde } 10,000 \text { TL'lik bir fon } \\
\text { olduğu varsayıldığında, } \\
\text { sermayemin (.............) } \\
\text { TL'sini yatırım yapardım: }\end{array}$ & $0.211 *$ & Kabul & Yok & $0.885^{*}$ & Kabul & Yok \\
\hline $\begin{array}{l}\text { Bu şirketin hisse senedi satın } \\
\text { alıarak yapılacak yatırımın } \\
\text { yüksek risk taşıdığını } \\
\text { düşünüyorum: }\end{array}$ & $0.521 *$ & Kabul & Yok & $0.258 *$ & Kabul & Yok \\
\hline $\begin{array}{l}\text { Elimde } 10,000 \text { TL'lik bir fon } \\
\text { olduğu varsayıldığında, bu } \\
\text { şirkete yatırım yapardım: }\end{array}$ & $0.515^{*}$ & Kabul & Yok & $0.686^{*}$ & Kabul & Yok \\
\hline $\begin{array}{l}\text { Bu şirketin hisse senedi alınarak } \\
\text { yapılacak bir yatırımdan diğer } \\
\text { finansal yatırım araçlarına göre } \\
\text { daha fazla kar elde edebilirim }\end{array}$ & $0.090 *$ & Kabul & Yok & $0.470 *$ & Kabul & Yok \\
\hline
\end{tabular}

*Mann-Whitney $\mathrm{U}$ testine göre olasilık değeri $>0,05 * \mathrm{H}_{0}$ hipotezi kabul edilmektedir.

\section{SONUÇ}

Çalışmada, şirketler tarafından yayınlanan kurumsal faaliyet raporlarında, bilgi sıralanması ile bu raporlarda yer alan grafiklerin, yatırımcıların kararları ve şirketle ilgili görüşleri üzerindeki etkisi araştırılmıştır. Literatürde yapılmış araştırmalarda, İ̈BF öğrencileri "geleceğin yatırımcıları" olarak sıfatlandırılmıştır. Buna istinaden, bu yatırımcıların şirketler tarafından sürekli yapılan açıklamalar, basın bültenleri ve raporlardaki olası manipülasyona duyarlılığı ve hile kullanımının yatırımcıların yatırım kararının üzerindeki etkisinin araştırılması öne sürülmektedir. Araştırmada ulaşılan bulgularda, teknik analiz, temel analiz bilgisi, şirket haberleri ile ilgili web siteleri takibi ve hisse senedi alım satımında deneklerin 40'1 $(\% 9,5)$ tüm bu özelliklere tecrübeye sahip olduğu bulunmuştur. Sonuçlar, bilgi sıralanmasında değişiklik yapıldığında veya grafikler bulunduğunda, bölümden bölüme farklı etkilerin ortaya çıtığını göstermektedir.

Sonuçlar genelde, bilgi sıralanmasında yapılan değişikliklerle ilgili, profesyonel olmayan yatırımcıların yenilik etkisine duyarlılığını göstermektedir. Bilgi sıralanması yatırım kararını etkilemezken yatırımcının yatırmak istediği miktarı ve beklenen kârı etkilemiştir. Ayrıca, olumsuz bilgilerin ardından olumlu bir grafiğin bulundurulması, profesyonel olmayan yatırımcının kararını neredeyse etkilemediğini göstermektedir. $\mathrm{Bu}$ etkiler kadın yatırımcıların kararlarında varken, erkeklerde bulunmamıştır. Erkeklerin yatırımla ilgili fikirleri, bağımsız değişkenlerden etkilenmezken, kadınların kararları etkilenmiştir.

1. Bütün olarak, İşletme, Bankacılık ve Finans, İktisat ve Maliye öğrencileri için; bilgi sıralanması veya haberlerin faaliyet raporundaki yer değiştirilmesi, yatırım kararı alma sürecindeki fikirleri etkilemiştir. Şirketin faaliyet raporunda yer alan kötü haberlerden sonra olumlu bir grafik bulunmasının ise yatırımcıların üzerinde hiçbir etkiye sahip değildir. Bu sonuç Hellmann vd. (2017)'nin ulaştığı sonuçları desteklemektedir.

i. Bankacılık ve finans: Çalışmada kullanılan iki bağımsız değişkenin Bankacılık ve Finans bölümü öğrencileri üzerinde bir etkisi bulunmamaktadır.

ii. İktisat: Çalışmada kullanılan iki bağımsız değişkenin İktisat bölümü öğrencileri üzerinde bir etkisi bulunmamaktadır.

iii. Işletme: Çalışmada kullanılan iki bağımsız değişkenin İşletme bölümü öğrencileri üzerinde bir etkisi bulunmamaktadır.

iv. Maliye: Maliye bölümü öğrencileri üzerinde ikinci bağımsız değişkenin (grafik) bir etkisi bulunmamaktadır. Birinci bağımsız değişken ise (bilgi sıralanması) yatırımcının yatırmak istediği para miktarını ile bu yatırımdan kâr beklentisini olumlu bir şekilde etkilemiştir.

2. İ̈BF diğer bölümlerinde ${ }^{5}$ okuyan öğrenciler için; grafiğin yatırımcının sadece yatırım kararını etkilemiştir. Ayrıca, metin sıralamasında yapılan değişikliklerinden hiç etkilenmemiştir.

3. İİBF'de eğitim görmeyen üniversite öğrencilerin sonuçları ise bu öğrencilerin ne metin sıralamasındaki değişikliklerden ne de grafikten etkilenmediğini göstermektedir.

${ }^{5}$ (Uluslararası İlişkiler, Ekonometri, Siyaset Bil. ve Kamu Yönetimi, Çalışma Ekonomisi ve Endüstri İlişskileri, Sağlık Yönetimi, Turizm İşletmeciliği ve Sosyal Hizmet) 
4. Sonuçları özetleyerek, yenilik etkisi, İ̈BF öğrencilerinde bulunmakta olup, İİB dışı öğrencilerinde bulunmamaktadır. Ayrıca, profesyonel olmayan yatırımcıların karar alma sürecinde kadın öğrencilerin fikir ve görüşleri üzerinde bulunan yenilik etkisinin erkek öğrencilerin kararları üzerinde etkisi bulunmamıştır.

Faaliyet raporlarının hazırlama sürecinde dikkat edilmesi gereken hususlardan, bu raporun içerdiği bilgilerin doğru olması ile istatistiki verilerin ve analizlerin sade ve açık olmasıdır (Yıldırım, 2009). Ancak, araştırmada ulaşılan bulgular, bilgilerde bir değişikliğin olmadığı halde, bilgi sunum sıralanmasında yapılan değişikliklerin yatırımcının kararını etkileyebileceğini göstermektedir. Ayrıca, bu tür raporların içerdiği bilgilerin başka bir yerde bulunması neredeyse mümkün değildir. Buna dayanarak, faaliyet raporlarının yatırımcı kararının üzerindeki etkisini daha geniş ölçüde belirlemek üzere, gelecekte yapılacak araştırmalarda, bilgi sunum sıralanmasının yanında, faaliyet raporu hazırlanırken, şirketler tarafından grafiklerin ölçüm bozulması vb. yapılabilecek manipülasyonların araştırılması beklenmektedir. Bununla birlikte, sonuçlar bu tür belgelerin ve raporların üzerindeki uygulanan denetim işlemlerinin güçlendirilmesinin gerekliliğini göstermekte ve standardizasyon ihtiyacını gerektirmektedir.

Tablo 22. Tüm Bölümler: Hipotezlerin Testi

\begin{tabular}{|c|c|c|c|c|c|c|c|c|}
\hline \multirow{2}{*}{\begin{tabular}{l|} 
Bölüm \\
Hipotez
\end{tabular}} & \multicolumn{2}{|c|}{ Tüm veriler } & \multicolumn{2}{|c|}{ İ̈BF $^{6}$} & \multicolumn{2}{|c|}{$\begin{array}{l}\text { Bankacılık ve } \\
\text { Finans }\end{array}$} & \multicolumn{2}{|c|}{ İktisat } \\
\hline & Sig. & Karar & Sig. & Karar & Sig. & Karar & Sig. & Karar \\
\hline H1a & 0.510 & Ret & 0.005 & Kabul & 0.062 & Ret & 0.516 & Ret \\
\hline $\mathrm{H} 2 \mathrm{a}$ & 0.796 & Ret & 0.419 & Ret & 0.915 & Ret & 0.382 & Ret \\
\hline $\mathrm{H} 1 \mathrm{~b}$ & 0.000 & Kabul & 0.000 & Kabul & 0.168 & Ret & 0.154 & Ret \\
\hline $\mathrm{H} 2 \mathrm{~b}$ & 0.437 & Ret & 0.371 & Ret & 0.885 & Ret & 0.926 & Ret \\
\hline $\mathrm{H} 1 \mathrm{c}$ & 0.248 & Ret & 0.777 & Ret & 0.589 & Ret & 0.271 & Ret \\
\hline $\mathrm{H} 2 \mathrm{c}$ & 0.442 & Ret & 0.296 & Ret & 0.606 & Ret & 0.063 & Ret \\
\hline H1d & 0.100 & Ret & 0.006 & Kabul & 0.114 & Ret & 0.112 & Ret \\
\hline $\mathrm{H} 2 \mathrm{~d}$ & 0.777 & Ret & 0.446 & Ret & 0.660 & Ret & 0.590 & Ret \\
\hline H1e & 0.006 & Kabul & 0.010 & Kabul & 0.264 & Ret & 0.705 & Ret \\
\hline $\mathrm{H} 2 \mathrm{e}$ & 0.719 & Ret & 0.537 & Ret & 0.296 & Ret & 0.123 & Ret \\
\hline Bölüm & \multicolumn{2}{|c|}{ İşletme } & \multicolumn{2}{|c|}{ Maliye } & \multicolumn{2}{|c|}{ İ̈BF $(B)^{7}$} & \multicolumn{2}{|c|}{ İ̈BF dışı } \\
\hline Hipotez & Sig. & Hipotez & Sig. & Hipotez & Sig. & Hipotez & Sig. & Hipotez \\
\hline $\mathrm{H} 1 \mathrm{a}$ & 0.081 & Ret & 0.113 & Ret & 0.568 & Ret & 0.847 & Ret \\
\hline $\mathrm{H} 2 \mathrm{a}$ & 0.547 & Ret & 0.356 & Ret & 0.105 & Ret & 0.385 & Ret \\
\hline $\mathrm{H} 1 \mathrm{~b}$ & 0.066 & Ret & 0.003 & Kabul & 0.851 & Ret & 0.211 & Ret \\
\hline $\mathrm{H} 2 \mathrm{~b}$ & 0.460 & Ret & 0.315 & Ret & 0.792 & Ret & 0.885 & Ret \\
\hline $\mathrm{H} 1 \mathrm{c}$ & 0.181 & Ret & 0.563 & Ret & 0.236 & Ret & 0.521 & Ret \\
\hline $\mathrm{H} 2 \mathrm{c}$ & 0.577 & Ret & 0.467 & Ret & 0.414 & Ret & 0.258 & Ret \\
\hline H1d & 0.442 & Ret & 0.116 & Ret & 0.708 & Ret & 0.515 & Ret \\
\hline $\mathrm{H} 2 \mathrm{~d}$ & 0.960 & Ret & 0.691 & Ret & 0.039 & Kabul & 0.686 & Ret \\
\hline $\mathrm{H} 1 \mathrm{e}$ & 0.181 & Ret & 0.015 & Kabul & 0.573 & Ret & 0.090 & Ret \\
\hline $\mathrm{H} 2 \mathrm{e}$ & 0.167 & Ret & 0.696 & Ret & 0.229 & Ret & 0.470 & Ret \\
\hline
\end{tabular}

${ }^{6}$ (Bankacılık ve Finans, İşletme, Maliye ve İktisat)

${ }^{7}$ (Uluslararası İlişkiler, Ekonometri, Siyaset Bil. ve Kamu Yönetimi, Çalışma Ekonomisi ve Endüstri İlişkileri, Sağlık Yönetimi, Turizm İşletmeciliği ve Sosyal Hizmet) 


\section{KAYNAKLAR}

Adelberg , A. H. (1979). Narrative Disclosures Contained in Financial Reports: Means of Communication or Manipulation? Accounting and Business Research, 9(35). doi:10.1080/00014788.1979.9729157

Agnew , K. (2016). The Effect of Presentation Format on Investor Judgments and Decisions Does the Effect Differ for Varying Task Demands (Cilt Doktora tezi). Florida: University of South Florida.

Baird, J. E., \& Zelin, R. C. (2000). The Effects of Information Ordering on Investor Perceptions: An Experiment Utilizing Presidents' Letters. Journal of Financial and Strategic Decisions, 13(3).

Beattie, V., \& Jones, M. J. (1992). The Use and Abuse of Graphs in Annual Reports: Theoretical Framework and Empirical Study. Accouniing and Business Research, 22(88), 291-303.

Beattie, V., \& Jones, M. J. (2000). Changing Graph Use in Corporate Annual Reports: A Time-Series Analysis. Contemporary Accounting Research, 17(2), 213-226.

Berry, J. (2015). Recency Effects. Psychology and Behavioral Health, 1571-1574.

Borsa İstanbul. (2014). Şirketler için Sürdürülebilirlik Rehberi. Borsa İstanbul.

Clatworthy , M., \& Jones, M. J. (2003). Financial reporting of good news and bad news: evidence from accounting narratives. Accounting and Business Research, 33(3), 171-185.

Deloitte. (2014). Anonim ve Limited Şirketler Için Yıllık Faaliyet Raporu Hazırlama Kılavuzu. Türkiye Kurumsal Yönetim Derneği ve Deloitte ortak yayını.

Demirgil, H. (2014). Parametrik Olmayan Hipotez Testleri. Ş. Kalaycı (Dü.) içinde, SPSS Uygulamalı Çok Değişkenli İstatistik Teknikleri. Ankara, Asil Yayın Dağıtım.

Elliott , W. B., Hodge , F. D., Kennedy , J. J., \& Pronk , M. (2007). Are M.B.A. Students a Good Proxy for Nonprofessional Investors? The Accounting Review, 82(1), 139-168.

Glen, S. $\quad(2016,10$ 16). Order Effects. 6 15, 2019 tarihinde Statistics How To: https://www.statisticshowto.datasciencecentral.com/order-effects/ adresinden alındı

Greenlees, I., Dicks, M., Holder, T., \& Thelwell, R. (2007). Order effects in sport: Examining the impact of order of information presentation on attributions of ability. Psychology of Sport and Excercise(8), 477-489.

Guarino, A. (2017, Kas 16). Mann -Whitney - Wilcoxon Test - Examples. May 2019 tarihinde Université de la Réunion: https://blog.univ-reunion.fr/alessioguarino/2017/11/16/mann-whitney-wilcoxon-test-examples/ adresinden alınd

Hellmann, A., Yeow , C., \& De Mell, L. (2017). The influence of textual presentation order and graphical presentation on the judgements of nonprofessional investors. Accounting and Business Research, 47(4). doi: $10.1080 / 00014788.2016 .1271737$

Hines, R. D. (1982). The Usefulness of Annual Reports: the Anomaly between the Efficient Markets Hypothesis and Shareholder Surveys. Accounting and Business Research, 12(48), 296-309.

Hogarth , R. M., \& Einhorn , H. J. (1992). Order Effects in Belief Updating: The Belief-Adjustment Model. COGNITIVE PSYCHOLOGY, 24, 1-55.

Karğin, S., Araci, H., \& Aktaş, H. (2013). Entegre Raporlama: Yeni Bir Raporlama Perspektifi. Muhasebe ve Vergi Uygulamalar1 Dergisi(1).

Kayış, A. (2014). Güvenilirlik Analizi. Ş. Kalaycı (Dü.) içinde, SPSS Uygulamalı Çok Değişkenli İstatistik Teknikleri (Cilt 1). Ankara: Asil Yayın Dağıtım.

Kennon, J. (2018, Mar 2). Annual Reports: What They Are and Why Investors Care. Haz 15, 2019 tarihinde The Balance: https://www.thebalance.com/annual-reports-what-they-are-and-why-investors-care-357304 adresinden alındı

Kılıç, S. (2016). Cronbach'ın Alfa Güvenirlik Katsayisi. Journal of Mood Disorders (JMOOD), 6(1), 47-48.

Kumkale, R. (2016, Şub 2). Şirketlerin yıllık faaliyet raporu hazırlama zorunluluğu. Haz 15, 2019 tarihinde Dünya: https://www.dunya.com/kose-yazisi/sirketlerin-yillik-faaliyet-raporu-hazirlama-zorunlulugu/26994 adresinden alındi

Lane, D. M. (2019). Online Statistics Education: An Interactive Multimedia Course of Study. Rice University. Haz 20, 2019 tarihinde http://onlinestatbook.com/2/logic_of_hypothesis_testing/nonsignificant.html adresinden alındı

LaSalle, R. E. (1997). Presentation Order Effects on Accounting Students' Ethical Judgments. Journal of Accounting Education, 15(1), 19-38.

Leppink, J. (2019). Models for Treatment Order Effects. Statistical Methods for Experimental Research in Education and Psychology, 243-254. doi:10.1007/978-3-030-21241-4_16.

Miller, M. J., \& Krosnick, A. J. (1998). The Impact of Candidate Name Order on Election Outcomes. Public Opimion Quarterly, 62(3).

Paul, R., \& Weiss, D. (2018). Primacy Effects. Encyclopedia of Autism Spectrum Disorders (Cilt 1). içinde Springer International Publishing AG. doi:10.1007/978-1-4614-6435-8_1116-3

Payne, J. W., Bettman, J. R., \& Johnson, E. J. (1993). The Adaptive Decision Maker. Cambridge University Press.

Pei, B. K., Reckers, P. M., \& Wyndelts, R. W. (1990). The Influence of Information Presentation Order on Professional Tax Judgment. Journal of Economic Psychology(11), 119-146.

Pinsker, R. (2011). Primacy or Recency? A Study of Order Effects When Nonprofessional Investors are Provided a Long Series of Disclosures. Behavioral Research in Accounting, 23(1), 161-183.

Psychology. (2019). Order Effects. 15 6, 2019 tarihinde Psychology: https://psychology.iresearchnet.com/socialpsychology/social-psychology-research-methods/order-effects/ adresinden alındı 
Recency Effect. (2019). Haz 15, 2019 tarihinde Survey Any Place: https://help.surveyanyplace.com/en/support/solutions/articles/35000041586-recency-effect adresinden alınd 1

Rey, A., Le Goff, K., Abadie, M., \& Courrieu, P. (2019). The Primacy Order Effect In Complex Decision Making. Psychological Research, 1-10.

Riley , T. J., \& Yen, A. C. (2019, Oca). Accounting Narratives. Oxford Research Encyclopedias. doi:10.1093/acrefore/9780190224851.013.169

Saban , M., küçüker , H., \& Küçüker , M. (2017). Kurumsal Sürdürülebilirlik İle İlgili Raporlama Çerçeveleri Ve Sürdürülebilir Raporlamada Muhasebenin Rolü. İşletme Bilimi Dergisi (JOBS), 5(1), 101-115. doi:10.22139/jobs.291818

Sauro, J. (2014, Eki 21). What Does Statistically Significant Mean? Haz 20, 2019 tarihinde Measuring U: https://measuringu.com/statistically-significant/ adresinden alınd1

Senter , S. M., \& Wedell, D. H. (1999). Information Presentation Constraints and the Adaptive Decision Maker Hypothesis. Journal of Experimental Psychology: Learning, Memory, and Cognition 1999, 25(2), 428-446.

Shaw , S., Nihalani, P., Mayrath, M., \& Robinson, D. H. (2012). Graphic organizers or graphic overviews? Presentation order effects with computer-based text. Education Tech Research Dev, 60, 807-820. doi:10.1007/s11423-0129257-2

Troyer , A. K. (2017). Recency Effect. Encyclopedia of Autism Spectrum Disorders. içinde Springer International Publishing AG.

TTK. (2011). Türk Ticaret Kanunu. Resmi Gazete: Tarih: 14/2/2011 Sayı : 27846.

Tuttle, B., Coller , M., \& Burton , F. G. (1997). An Examination of Market Efficiency: Information Order Effects in a Laboratory Market. Accounting, Organiration.s and Soctety, 22(1), 89-103.

Yankova, K. (2014). The Influence of Information Order Effects and Trait Professional Skepticism on Auditors' Belief Revisionss. Duisburg, Ger: Springer Fachmedien Wiesbaden.

Yıldırım, Ö. (2009). Yıllık Faaliyet Raporu Hazırlama Rehberi. Deloitte. 
EKLER

Ek1: Tüm Bölümlerin Yanıtları

\begin{tabular}{|c|c|c|c|c|c|c|c|}
\hline $\mathbf{H}$ & Soru & & & Seçenekler & & & \\
\hline \multirow{4}{*}{  } & $\begin{array}{l}\text { Elimde } 10,000 \text { TL'lik bir fon } \\
\text { olduğu varsayıldığında, } \\
\text { sermayenin (...............) } \\
\text { TL'sini yatırım yapardım: }\end{array}$ & 0 TL & 1 ile $2500 \mathrm{TL}$ & $\begin{array}{l}2501 \text { ile } 5000 \\
\text { TL }\end{array}$ & $\begin{array}{l}5001 \text { ile } 7500 \\
\text { TL }\end{array}$ & $\begin{array}{l}7501 \text { ile } \\
10,000 \text { TL }\end{array}$ & $\begin{array}{l}\text { Yanitların } \\
\text { Toplamı }\end{array}$ \\
\hline & Grup $1(+-)$ & 24 & 41 & 44 & 7 & 4 & 120 \\
\hline & Grup 2 (+-Grafik) & 18 & 51 & 40 & 10 & 8 & 127 \\
\hline & Grup $3(-+)$ & 14 & 53 & 63 & 29 & 12 & 171 \\
\hline \multirow{4}{*}{$\begin{array}{l}\hat{0} \\
\hat{\Xi} \\
\hat{\Xi}\end{array}$} & $\begin{array}{l}\text { SSirketin faaliyetlerini olumlu } \\
\text { değerlendirmekteyim }\end{array}$ & $\begin{array}{l}\text { Kesinlikle } \\
\text { katılmıyorum }\end{array}$ & Katılmıyorum & Kararsızım & Katılıyorum & \begin{tabular}{|l|} 
Kesinlikle \\
katılıyorum
\end{tabular} & \\
\hline & Grup $1(+-)$ & 6 & 27 & 31 & 42 & 14 & 120 \\
\hline & Grup 2 (+-Grafik) & 8 & 28 & 28 & 54 & 8 & 126 \\
\hline & Grup $3(-+)$ & 9 & 20 & 37 & 76 & 21 & 163 \\
\hline \multirow{4}{*}{ 苂 } & $\begin{array}{l}\text { Elimde } 10,000 \text { TL'lik bir fon } \\
\text { olduğu varsayıldığında, bu } \\
\text { şirkete yatırım yapardım: }\end{array}$ & $\begin{array}{l}\text { Kesinlikle } \\
\text { katılmıyorum }\end{array}$ & Katılmıyorum & Kararsızım & Katılıyorum & $\begin{array}{l}\text { Kesinlikle } \\
\text { katılıyorum }\end{array}$ & \\
\hline & Grup $1(+-)$ & 11 & 26 & 42 & 33 & 8 & 120 \\
\hline & Grup 2 (+-Grafik) & 12 & 23 & 56 & 28 & 8 & 127 \\
\hline & Grup $3(-+)$ & 7 & 28 & 69 & 57 & 11 & 172 \\
\hline \multirow{4}{*}{ 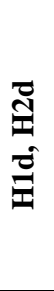 } & $\begin{array}{l}\text { Bu şirketin hisse senedi satın } \\
\text { alınarak yapılacak yatırımın } \\
\text { yüksek risk taşıdığını } \\
\text { düşünüyorum }\end{array}$ & $\begin{array}{l}\text { Kesinlikle } \\
\text { katılmıyorum }\end{array}$ & Katılmıyorum & Kararsızım & Katılıyorum & $\begin{array}{l}\text { Kesinlikle } \\
\text { katılıyorum }\end{array}$ & \\
\hline & Grup $1(+-)$ & 10 & 31 & 40 & 37 & 2 & 120 \\
\hline & Grup 2 (+-Grafik) & 15 & 40 & 36 & 29 & 8 & 128 \\
\hline & Grup $3(-+)$ & 6 & 37 & 75 & 42 & 11 & 171 \\
\hline \multirow{4}{*}{$\frac{\tilde{I}}{\tilde{I}}$} & $\begin{array}{l}\text { Bu şirketin hisse senedi } \\
\text { alınarak yapılacak bir } \\
\text { yatırımdan diğer finansal } \\
\text { yatırım araçlarına göre daha } \\
\text { fazla kar elde edebilirim }\end{array}$ & $\begin{array}{l}\text { Kesinlikle } \\
\text { katılmıyorum }\end{array}$ & Katılmıyorum & Kararsızım & Katılıyorum & $\begin{array}{l}\text { Kesinlikle } \\
\text { katılıyorum }\end{array}$ & \\
\hline & Grup $1(+-)$ & 13 & 28 & 50 & 26 & 3 & 120 \\
\hline & Grup 2 (+-Grafik) & 13 & 30 & 49 & 28 & 6 & 126 \\
\hline & Grup $3(-+)$ & 5 & 33 & 74 & 52 & 8 & 172 \\
\hline
\end{tabular}




\section{Ek2: İỉBF (A), İiBF (B) ve İiBF Dışı Cevaplarının Sıra Ortalamaları}

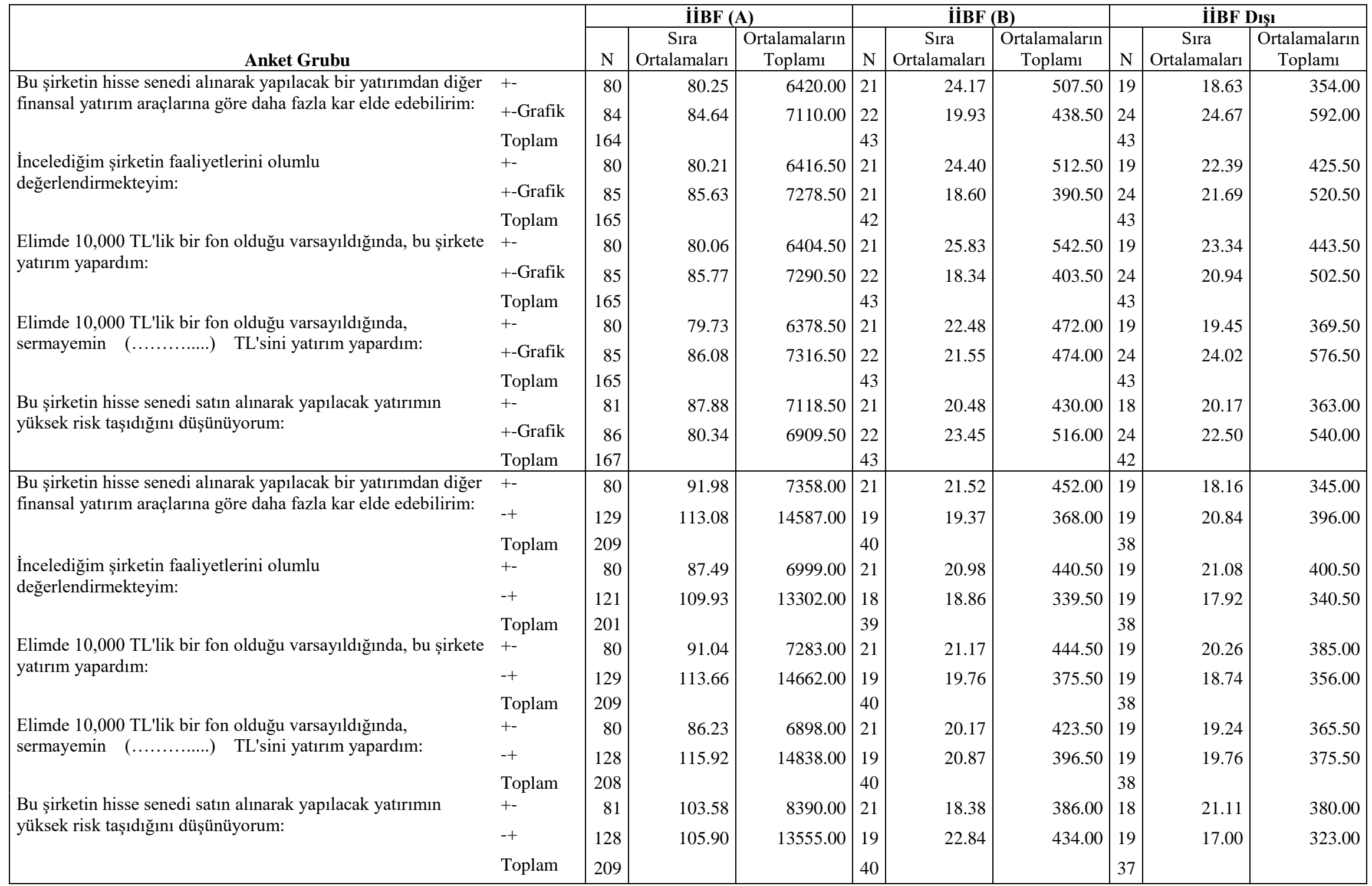

Selçuk Üniversitesi Sosyal Bilimler Meslek Yüksekokulu Dergisi, Yıl: 2020 Cilt: 23 Sayı:1 


\section{Ek3: “Olumlu-Olumsuz-Grafik" Faaliyet Raporu}

Nev-Mall 2018 Y1lı Faaliyet Raporu

Nev-Mall Mağazacılık, 2018 yılında, faaliyet gösterdiği il sayısını 81'e yükseltmis ve Türkiye'nin tüm illerinde hizmet vermeye başlamıștır. Nev-Mall sürdürülebilirlik alanındaki somut adımlarıyla 2014 yılından itibaren Borsa İstanbul Sürdürülebilirlik Endeksi’ne girmeye hak kazanmış ve 5 yıl üst üste endekste yer alan ilk ve tek gıda perakendecisi olmuştur. 1997 yılında kurulan ve Türkiye'nin ilk gıda perakende e-ticaret sitesi olan Nev-Mall E-ticaret, Nev-Mall markasını Türkiye'deki tüm hanelere ulaştırma vizyonu ile müşteri odaklılı̆̆ını stratejisinin merkezine konumlandırarak hizmet vermektedir. Türk perakende sektörünün öncüsü Nev-Mall, yurt dıșında Kazakistan ve Makedonya'da Lamča markasıyla hizmet vermektedir. Nev-Mall yurt dișında 26'sı Makedonya'da, 18'i Kazakistan'da ve olmak üzere toplam 44 mağazayla hizmet vermektedir. Mağazaları mevcut ülkelerde yaygınlaşırken, gelecekte yeni ülkelerde de bu yönde yatırım yapılması öngörülmektedir. Nev-Mall 2018 yılında güçlü bir büyüme performansı göstermiştir. Engelsiz Mağaza konseptine uygun olan Nev-Mall mağazalarında işitme engellilere yardımc olabilmesi için işaret dili bilen en az bir çalıșan bulunmaktadır ve müșteriler bu çalışanları yakalarındaki işaret dili bildiklerini belirten rozetlerden ayırt edebilmektedir. Şirket'in yurt içi satışları 2018 yılında \%21,7 büyürken, yurt dışı iştiraklerinin satışları \%34 artmıştır. Grup'un, 31 Aralık 2018 tarihi itibarıyla toplam ortalama çalışan sayıs1 28.990'dir. (31 Aralık 2017: 26.779). Ülkemizde geçtiğimiz yılın ikinci yarısında kurlarda yaşanan artış, mal ve hizmetlerin üretim maliyetlerini yaklaşık \%19,5 oranında arttırdı. Şirket dönemi hisse başına 4.6 TL kayıpla kapatmıştır. Bu faktörlerin de etkisiyle şirketin hisse senedi fiyatı 27.56'dan 14.9 TL düşüş göstermiştir (\%45.93). Sirketlerin daha ihtiyatlı yatırım stratejileri ile beraber, ekonomik büyüme, önceki y1llara göre düşüs gösterdi. İçinde bulunduğumuz yılın ilk aylarında ise, işsizlik rakamlarında artış görülse de kurlardaki dalgalanma boyu azaldı, geçen yıla göre enflasyon gerilemeye başladı ve ekonomi nispeten dengelenme sürecine girdi.
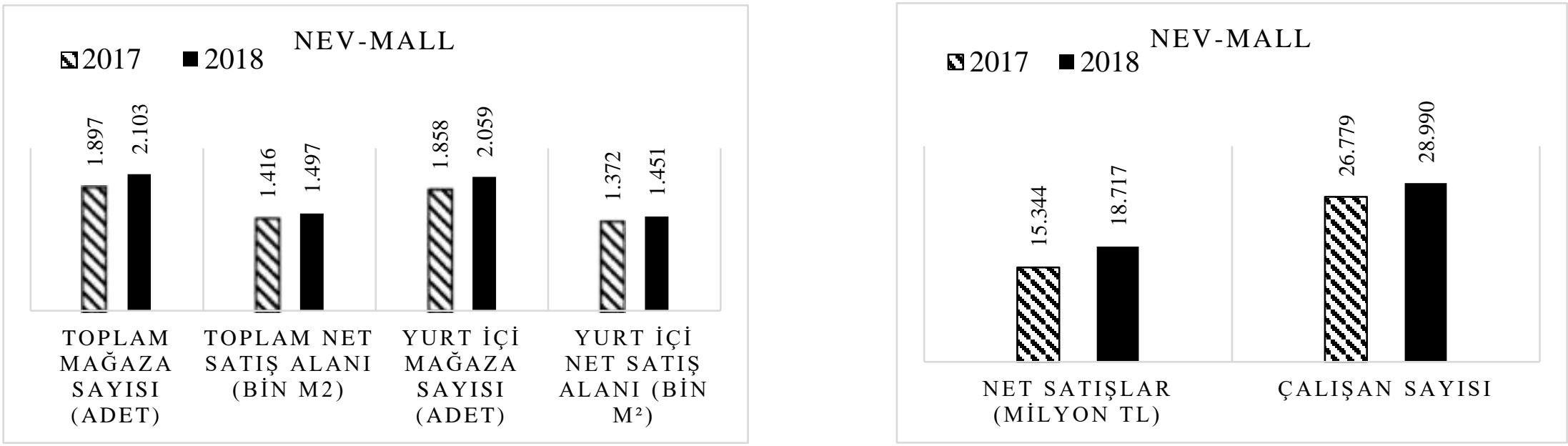

Selçuk Üniversitesi Sosyal Bilimler Meslek Yüksekokulu Dergisi, Yıl: 2020 Cilt: 23 Sayı:1 